$$
\text { FG03-92 ERT5833 }
$$

$$
\text { DOE/ER/75833-T5-Pt,I }
$$
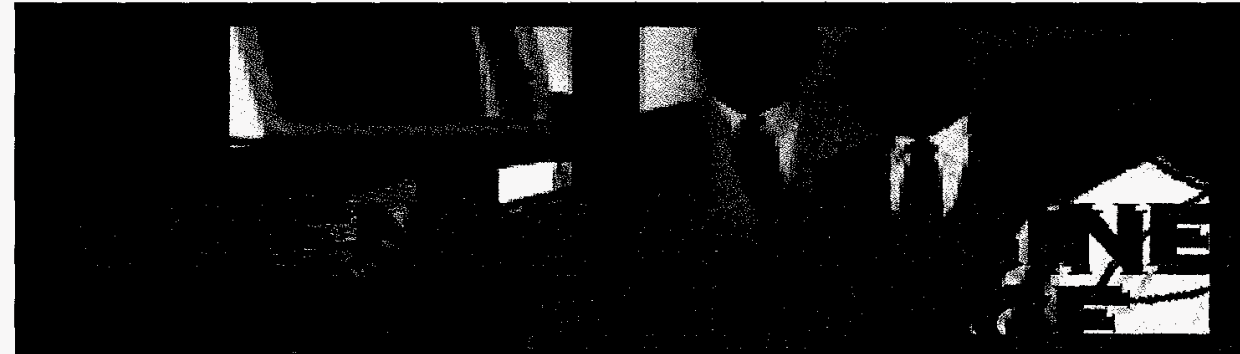

\title{
Infrastructure Development of the
} Science and Engineering Alliance (IDSEA)

\section{ANNUAL REPORT}




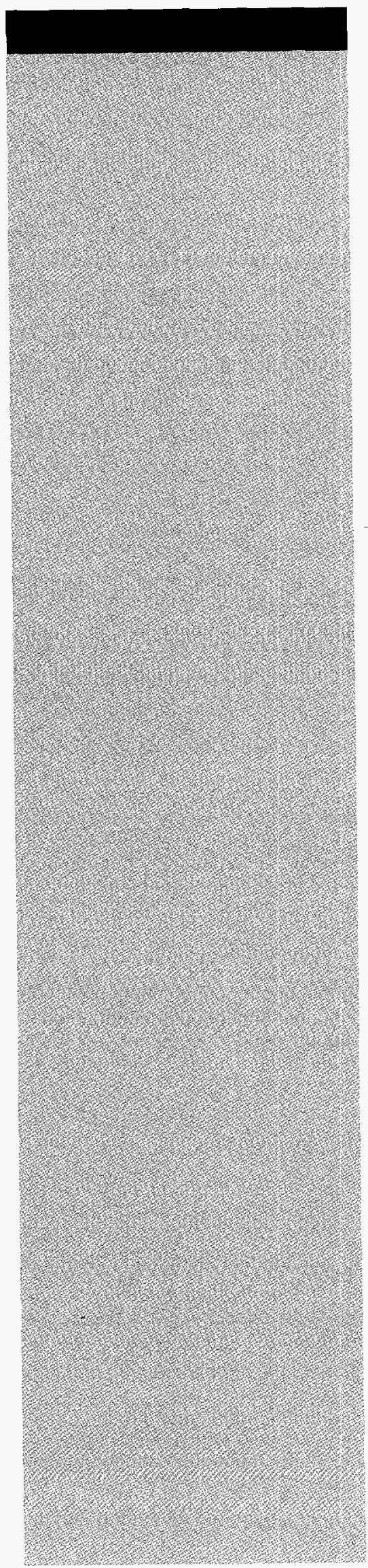

\section{ANNUAL REPORT}

\section{DISCLAIMER}

This report was prepared as an account of work sponsored by an agency of the United States Government. Neither the United States Government nor any agency thereof, nor any of their employees, makes any warranty, express or implied, or assumes any legal liability or responsibility for the accuracy, completeness, or usefulness of anly information, apparatus, product, or process disclosed, or represents that its use would not infringe privately owned rights. Reference herein to any specific commercial product, process, or service by trade name, trademark, manufacturer, or otherwise does not necessarily constitute or imply its endorsement, recommendation, or favoring by the United States Government or any agency thereof. The views and opinions of authors expressed herein do not necessarily state or reflect those of the United States Government or any agency thereof.

This document was prepared as an account of work sponsored by the U.S. Department of Energy (DOE) under grant number DE-FG0392ER75833. The views and opinions of authors expressed herein do not necessarily state or reflect those of the DOE or Lawrence Livermore National Laboratory.

\section{For Further Information Contact}

Robert L. Shepard, Ph.D., founding executive director of the Science and Engineering Alliance (SEA), 1522 K Street, N.W., Suite 210,

Washington, D.C. 20005. E-mail: rshepsea@aol.com; 202/842-0388 (voice); 202/842-0403 (fax); web: http//www.llnl.gov/sea/ 


\section{DISCLAIMER}

Portions of this document may be illegible electronic image products. Images are produced from the best available original document. 


\section{TABLE OF CONTENTS}

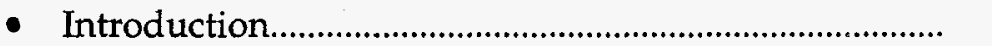

Program Summaries

- Infrastructure Development of the Science and Engineering Alliance (IDSEA).

- SEA High Performance Computing and Communication (HPCC).

- Scientific Database Management System.................. 8

- Integrated Scientific Simulation Environment Based on Distributed Computing.

- Data Management and Database Creation............. 10

- High Performance Computing in High-T $\mathrm{T}_{\mathrm{C}} . . . . . . . . . . . .11$

- Installation of a Synchrotron Radiation Beamline Facility at the J. Bennett Johnston, Sr. Center for Advanced Microstructure Devices (CAMD) for SEA....

- Structural Studies of Solid Polymer Electrolytes and Intercalation Cathode Materials of Solid State Batteries.

- Accelerated Illumination of Fluorinated Amorphous Silicon

- High Resolution X-ray Imaging Experiments.......... 15

- Materials for Photolithography and Other Photopatterning Applications.

- EXAFS Analysis of Sulfur K-edge in RockForming Minerals

- Investigations of Synchrotron Radiation Irradiated Surfaces and Interfaces in MOS Structures.

- Small Business Technology Transfer (STTR) Program..

- Synthetic Simultaneity: A Teleoperations Method for Remote Control of Extremely Distant Vehicles.. 18

- Community Environmental Justice Awareness Training (CEJAT) Project.

- Technical Assistance.

- High School Teacher Enhancement in the Sciences. 22

- Scientific Awareness Workshop for Culturally Diverse Colleges and Universities.

- Appendices.

Executive Summary from Teacher Workshop......... 26

- Executive Summary from Awareness Workshop... 30

- Evaluation of Distant Learning Course................... 36

- New Collaborations Between LLNL and SEA........ 38

- SEA Scholarship/Incentive Award Recipients....... 39

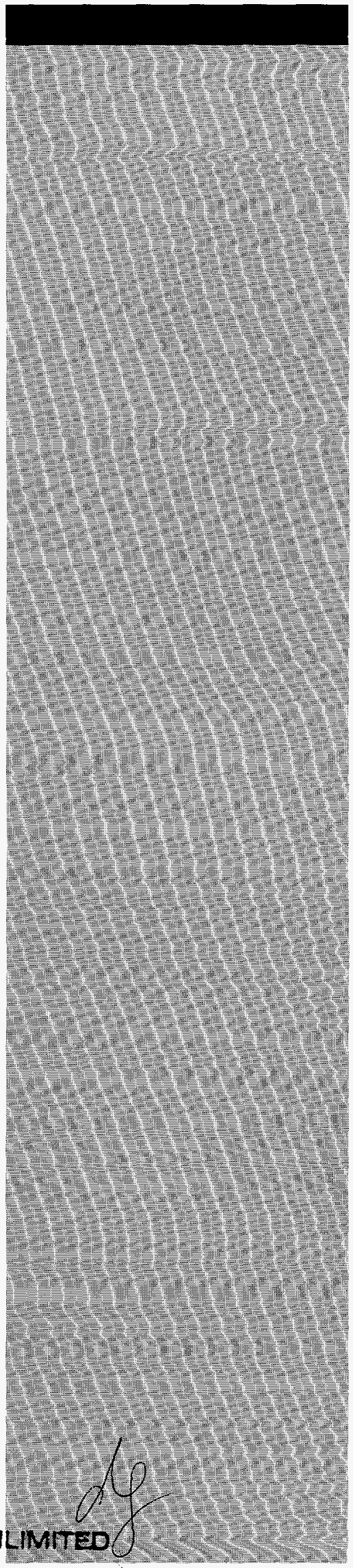




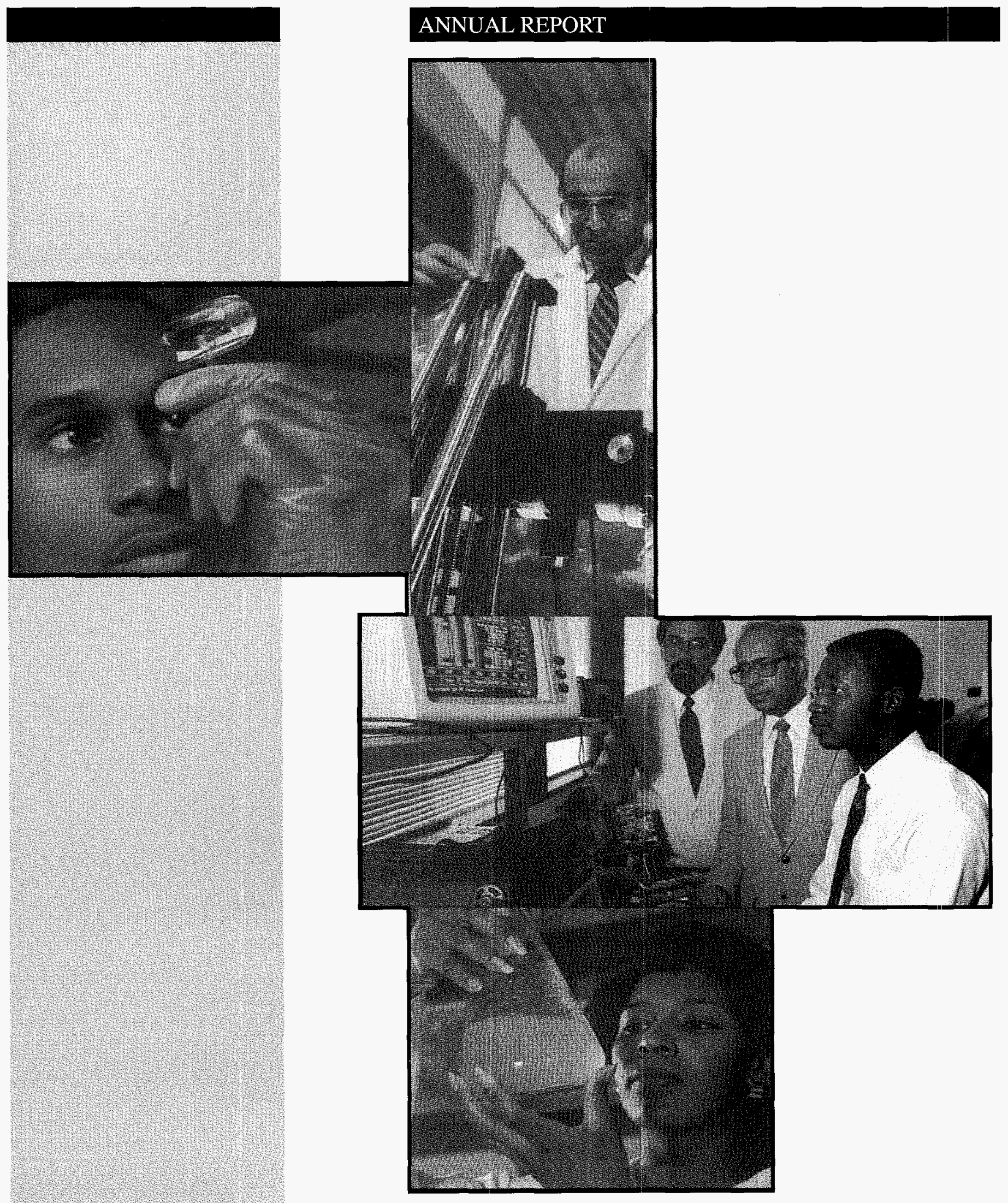




\section{INTRODUCTION}

\section{Purpose}

This document is intended to serve two purposes: (1) a program status report on the progress the Science and Engineering Alliance (SEA) made since receiving initial Department of Energy (DOE) support for infrastructure development; and (2) a summary report of the activities administered by the SEA compiled in a single document under the auspices of the SEA Program. In 1995, a universal resource locator (URL) on the World Wide Web (WWW) was established for easy access to pertinent information about the SEA Program. The information pointed to by the URL is updated periodically, and the interested reader is urged to access the WWW for more information. http://www.llnl.gov/sea/

\section{Background}

The Science and Engineering Alliance (SEA) is a universitygovernment-industry partnership that seek ways to enhance the research and teaching capability of its members. The SEA partnership is the outgrowth of a series of meetings in 1990 between the presidents of:

- Alabama A\&M University (Normal, AL);

- Jackson State University (Jackson, MS);

- Prairie View A\&M University (Prairie, TX);

- Southern University and A\&M College (Baton Rouge, LA); and

the laboratory associated director of: 
2 INTRODUCTION

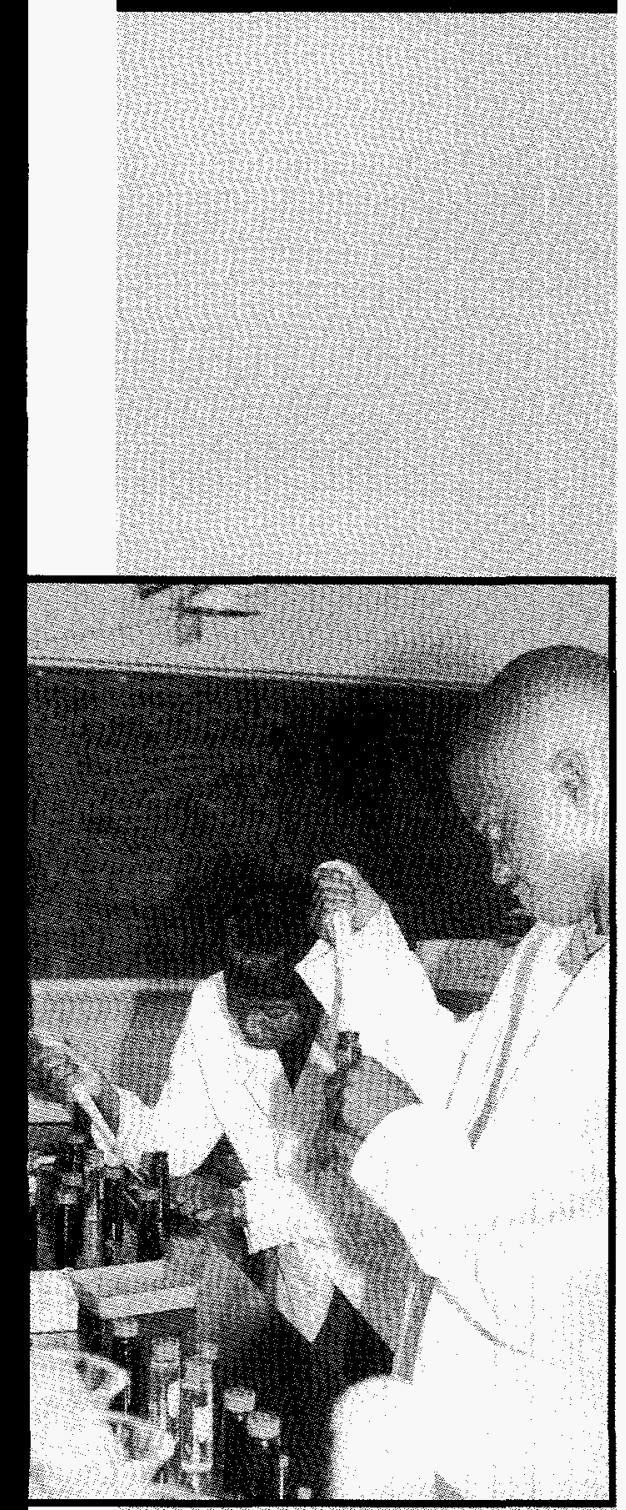

BACKGROUND

- Lawrence Livermore National Laboratory (LLNL) (Livermore, CA).

The meetings, spurred in large part by the reduction in resources for education and the government's and industry's commitment to improve science and mathematics education, set the stage for development of innovative partnerships aimed at expanding the pool of technical talent for the nation's future workforce.

The $S E A$ was formally established in a signing ceremony and reception on February 21, 1990, by the presidents of the four Historically Black Colleges and Universities (HBCUs), in Room 334 of the Cannon House Office Building in Washington, D.C. On June 26 of the same year, the SEA signed an agreement with LLNL to establish programs for advancing knowledge in the physical sciences and engineering. An executive director (ED) was hired October 1,1990, and charged with the responsibility of developing, implementing and institutionalizing the SEA, and moving it forward.

The SEA program continues to evolve into a very successful interdisciplinary program. It is a model inter-HBCU collaboration, and an excellent example of how cooperation between universities and a national laboratory can capitalize on their individual strengths to expand research opportunities for minority students and researchers. The members are committed to developing collaborative research programs, enhance teaching techniques, and modify science and engineering curriculum to improve student training.

During the past seven years, the ED has given numerous presentations on the SEA to various groups. These groups continue to cite the success of the SEA, and call for the federal 
government and private industry to provide more support so that greater services can be delivered through the program.

This Final Report presents to DOE, the results of their initial investment in the infrastructure development of the SEA, and highlights anticipated objectives holding great promise for the continued growth and development of the SEA mission. rshepsea@aol.com

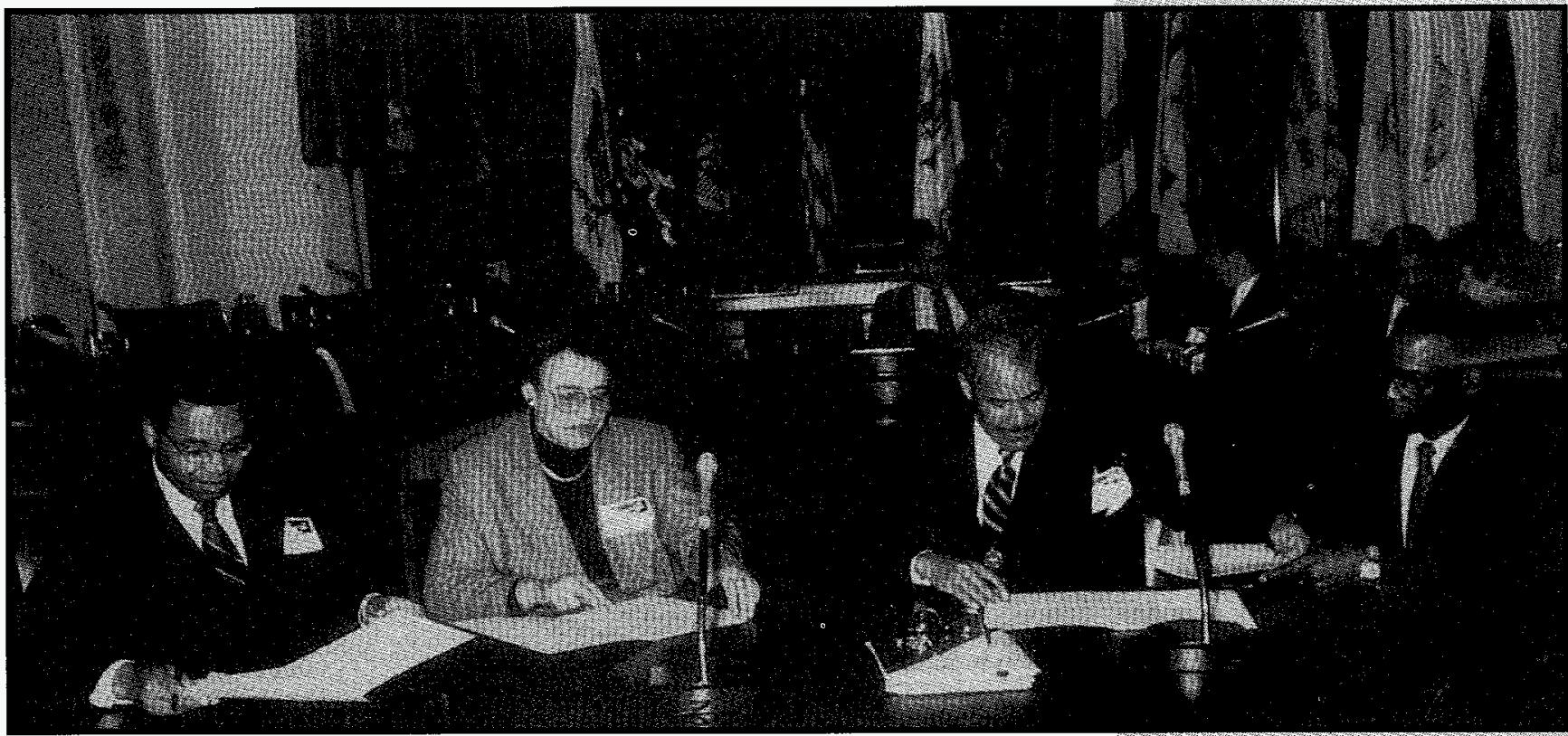

On Feb. 21, 1990, the presidents of Alabama A\&M University, Jackson State University, Prairie View A\&M University, ond Southern University and A\&M College signed the agreement formally establishing the Science and Engineering Alliance. The signing ceremony was held in the Cannon House Office Building in Washington, D.C. 

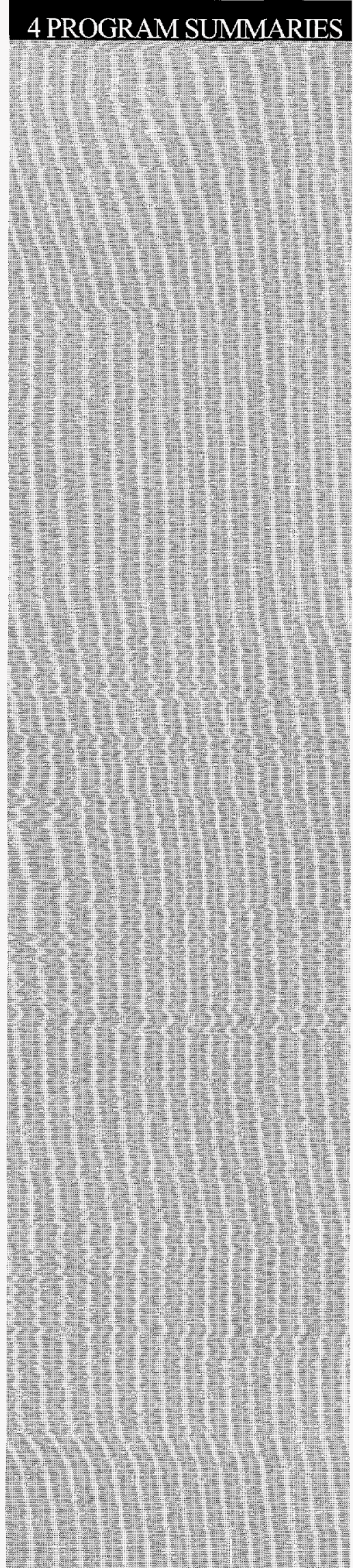

IDSEA

\section{PROGRAM SUMMARIES}

\section{Infrastructure Development of the Science and Engineering Alliance (IDSEA)}

Co-PIs: Willie Trotty ${ }^{a}$, Robert Shepard $b$

Institutions: aPrairie View A\&M University, bSEA

Headquarters

willie_trotty@pvamu.edu

rshepsea@aol.com

In the first quarter of 1991, the SEA executive director and steering committee developed a 'blueprint' for increasing the participation of underrepresented groups in science and technology. The blueprint formed the basis for initiating an infrastructure development program to enhance the collective capabilities of the member institutions. By effectively linking the member institutions, the SEA can help ensure an adequate supply of quality African-American scientists and engineers for now and into the next century. Also, the linkage provide a more effective and efficient means of meeting the research and development needs of the public and private sector.

Therefore, the blueprint focused on the members working together to:

- undertake tasks of higher risk with higher payoff;

- enhance student marketability;

- expose the ability of HBCUs to conduct technology transfer;

- reduce costs; and

- make more efficient use of limited resources.

In the second quarter of 1991, LLNL implemented an element of the blueprint in the form of a summer research program for SEA 
faculty and students. In the last quarter of 1991, the blueprint was formed into a proposal entitled "Infrastructure Development of the Science and Engineering Alliance (IDSEA)." IDSEA is organized around five major mission areas:

- Develop and implement new initiatives that will foster collaborations among the members and strengthen faculty and student development;

- Create partnerships that build on the members' existing technical capabilities as a basis for improving the research infrastructure;

- Establish faculty and student internships and coops;

- Provide financial support to undergraduate and promising high students in the form of scholarships and incentive awards; and

- Prepare existing and prospective K-12 teacher to teach science and mathematics more effectively.

In January 1992, the IDSEA proposal was submitted to the U.S. Department of Energy's (DOE) Office of Science Education for funding consideration. Following peer review and subsequent modifications, DOE funded the IDSEA proposal in September 1992 for three years at a revised funding level of $\$ 888,746$. The funding supported start-up activities over the period of September 1992 to October 1996 (the fourth year was a no-cost extension to the existing three-year grant).

IDSEA was used to leverage funding for several new long-range research collaborations among the SEA members. These include:

- SEA High Performance Computing and Communication Program (funded by DOE);

- Installation of a Synchrotron Radiation Beamline Facility at the J. Bennett Johnston, Sr. Center for Advanced

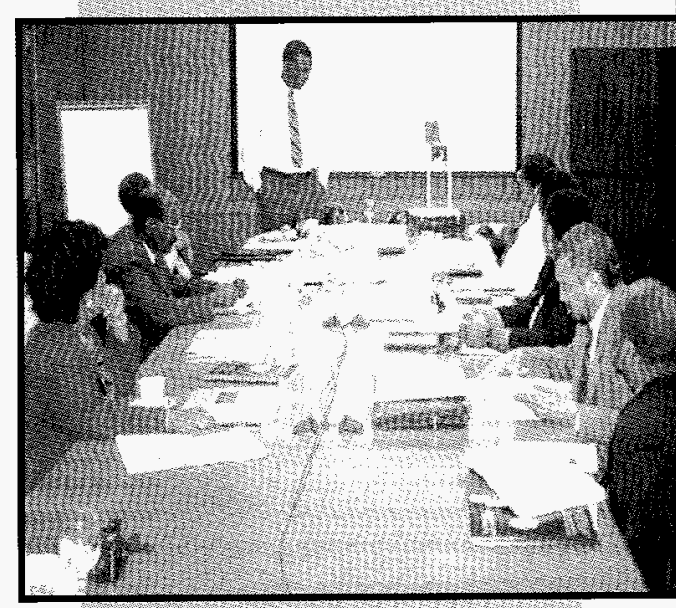




\section{PROGRAM SUMMARIES}

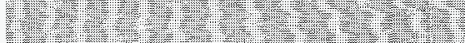

1. PIt wet yututy Putury

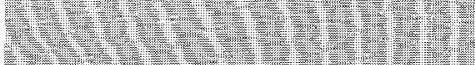
1)

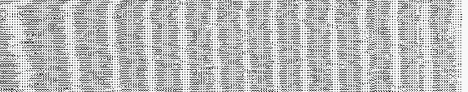

Microstructure Devices (CAMD) for the Science and Engineering Alliance (funded by DOE);

- Synthetic Simultaneity: A Teleoperations Method for Remote Control of Extremely Distant Vehicles (funded by NASA); and

- Community Environmental Justice Awareness and Training (funded by EPA).

Other activities flowed from the IDSEA effort. A Technical Assistant (TA) initiative was implemented to support smaller HBCUs. This initiative was instrumental in SEA securing EPA funding to conduct a scientific awareness workshop for culturally diverse colleges and universities.

Funds from the IDSEA were used to augment the teacher enhancement workshops supported by a grant from the Department of Education's Fund for Improvement of Postsecondary Education (FIPSE). Also, the IDSEA funds provided financial support for students in the form of scholarships and incentive awards.

In response to a peer reviewers' comment that the IDSEA appeared to be simply a loose connection of institutions, a distant learning course was developed and implemented. The course uses technology to better serve the needs of the SEA students. The distant learning technology allows students to benefit from the best that each member has to offer, without transporting students over long distances.

The Appendix section contains additional details. 


\section{SEA High Performance Computing and Communication (HPCC)}

PI: Kunal Ghosh

Institution: Jackson State University

kghosh@ccaix.jsums.edu

In February 1993, SEA scientists involved in high performance computing and communications (HPCC) research met at Jackson State University to develop a framework for moving forward with an expanded collaborative initiative. An SEA-HPCC Design Team was formed. By March 1993, abstracts were submitted by the SEA scientists. By May 1993, a "Talking Paper for Marketing Purposes (TPMP) was completed. The TPMP was composed of an executive summary, expertise tables, and was classified into six sub-areas of research:

- Global Change;

- Biotechnology and Biomedical;

- Data Acquisition, Storage, Processing and Integration;

- Toxic Waste;

- High Performance Computational Issues in Materials Science and High Energy Physics; and

- Outreach.

In June 1993, the executive director began marketing the TPMP. In January 1994, DOE showed interest and chose one project from each institution as possible candidates for funding. In April 1994, the SEA-HPCC proposal was officially submitted to the DOE. Following peer review and modifications, the SEA-HPCC initiative was funded by DOE's Office of Scientific Computing for three years at a revised funding level of $\$ 1,069,200$.

The HPCC proposal development process became the standard process for developing other SEA research initiatives. 
8 PROGRAM SUMMARIES

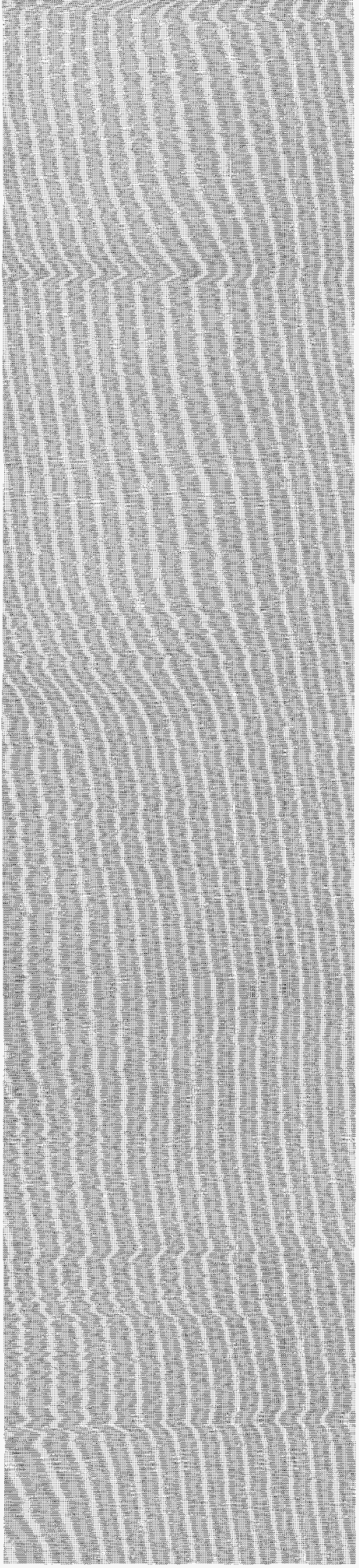

\section{HPCC}

The current SEA-HPCC project funded by DOE is entitled "Database Creation, Management, and Integration: Novel Methodologies, Techniques and Technologies." It has four subprojects that are briefly described below:

\section{Scientific Database Management System \\ Co-PIs: John Caulfield, Marius Schamschula Institution: Alabama A\&M University \\ hjc@dubois.fisk.edu \\ marius@caos.aamu.edu}

The goal of this project is to address the issues pertaining to the "information age," where vast quantities of information speed along data superhighways, supercomputers, and terabit memories are under construction. There is a high probability that conventional Scientific Data Base Management Systems (SDBMS) will prove woefully inadequate.

In this case, it makes sense to use the technology of modern data communication storage, and processing for SDBMS. The goal of this project is to use optics and optical SDBMS technology to replace conventional SDBMS. We seek dramatic improvements in access time. This is being accomplished through four tasks:

- Develop the logic for optical parallel SDBMS;

- Demonstrate recall via Joint Transform Correlators;

- Demonstrate parallel search of SDBMSs by Adaptive Resonsance; and

- Artificial neural network application

The expected outcomes will be a much faster search of ultra large SDBMS and a convenient crisp and fuzzy logic in parallel 
to control the SDBMS. In the long term, we expect to solve all of the SDBMS problems in this grant, and we hope to point the way to future research and keep HBCUs involved in this forefront effort.

\section{Integrated Scientific Simulation Environment Based on Distributed Computing}

PI: Gwang Jung

Institution: Jackson State University

gsj@dragon.jsums.edu

The goal of this project is to design, implement, test, and evaluate an Integrated Scientific Simulation Environment (ISSE). If successful, the ISSE design will provide program development tools, scientific visulization/graphics/image processing tools, bibliographical reference tools, and video/image retrieval tools in one screen with multiple windows for the entire life cycle of scientific simulation. By having such an integrated environment, the vast human resources and effort required for developing such models can be dramatically reduced.

In addition, high quality and reliable simulation results can be effectively obtained. ISSE should work on any platform connected to the network, and should utilize various hardware/software resources available on any other platforms connected to the network. 
10 PROGRAM SUMMARIES

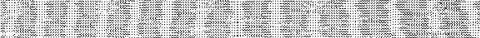
19. 1.9. (1) (1) Wf(t) P(t) UI: W Futs: V.: P.

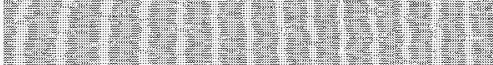

\section{HPCC}

\section{Data Management and Database Creation}

\author{
PI: Anil Kumar
}

Institution: Prairie View A\&M University

akumar@pvcea.pvamu.edu

This project addresses the issues of data management, database creation, and database management with specific implementation strategies in selected practical situations. The purpose of this project is fourfold:

- To apply principles of data collection, data storage, data retrieval and data transfer to create database prototypes for several explicit physical problems;

- Validate and verify prototypes, then implement the prototypes on various platforms operating under custom-built (objectoriented databases - OODBs with the appropriate safety and password protocols) and public domain software (such as ORACLE);

- Effect technology transfer of the prototypes to DOE and industry; and

- Educate and train graduate and undergraduate students, especially African American and other minorities, in this important area.

Several relevant aspects of software engineering are being addressed in regards to centralized vs. distributed data storage:

- Reliability and tolerance to corruptibility of the databases due to distributed architectures;

- Effect of network reliability on the database reliability in distributed systems;

- Validation and verification;

- Reusability of the databases; 
- Recommendations regarding optimal testbeds; and

- Capability to adapt to various network protocols.

While research is a major aspect of this project, the underlying philosophy is also functional, viz., to find the best system of what seems stable today and use it for building of prototypes of databases and interoperable configurations.

\section{High Performance Computing in High- $\mathrm{T}_{\mathrm{C}}$}

PI: Jiang-Di Fan

Institution: Southern University and A\&M College

phjola@lsuvax.sncc.lsu.edu

This project studies high-performance computing of high temperature superconductivity. This represents an expansion of a project supported by the Air Force Office of Scientific Research for the past three years. In that project, a breakthrough was made in high-Tc by finding out an amazingly good pair interaction potential in a layered two-dimensional system. In the current project, researchers intend to make numerical and simulation computations of four important physical quantities:

- Transition temperature Tc;

- Order parameter ;

- Transport properties of high-Tc in the normal state; and

- Magnetic ordering of high-Tc superconductors.

By the end of the project, researchers hope to use theory, supported by both analytical and computational results, as a realistic model to explain high temperature superconductivity.

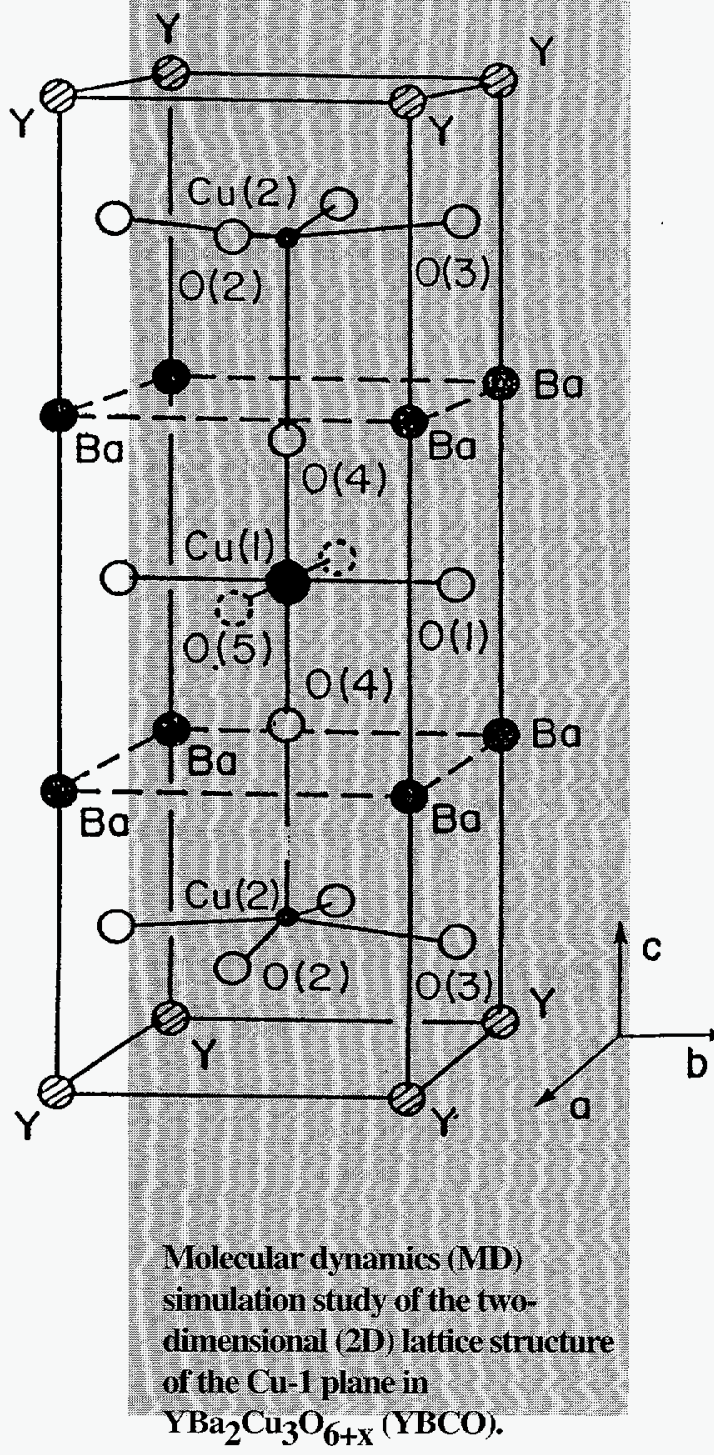




\section{PROGRAM SUMMARIES}

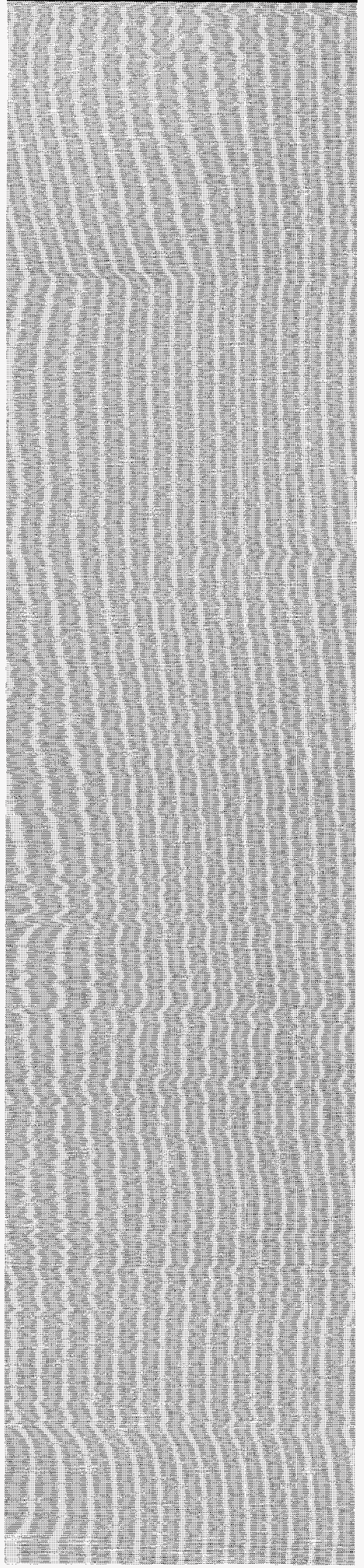

\section{HPCC}

\section{Summary of the SEA HPCC Program}

To ensure that the SEA activity is in accord with DOE's overall HPCC mission, the SEA PIs and Lawrence Berkeley National Laboratory (LBNL) met on January 27-28, 1997, to forge a partnership between the two groups. Several areas were identified as showing potential for collaboration between LBNL and the SEA. The SEA is developing its draft proposals for LBNL review. The final proposal submitted to DOE will reflect the synergy of the SEA effort, and its relationship to the LBNL HPCC program. 


\section{PROGRAMSUMMARIES 13}

Installation of a Synchrotron Radiation Beamline Facility at the J. Bennett Johnston, Sr. Center for Advanced Microstructure and Devices (CAMD) for the Science and Engineering Alliance

PD: Robert Gooden

Institution: Southern University and A\&M College

rtgooden@aol.com

The Office of Energy Research of the Department of Energy (DOE) funded a proposal to support a number of research projects to be carried out, in part, using the existing beamline facilities at The J. Bennett Johnston, Sr. Center for Advanced Microstructures and Devices (CAMD) in Baton Rouge, Lousiana. The grant award totaled $\$ 600,000$ over a three-year period. The research projects of this grant, and new term renewals, are focused in four areas:

- X-ray Optics;

- Materials Science;

- EXAFS and Other X-ray Analyses; and

- Electronic Device Development.

Depending on the success of this initial phase, the long-term goal is to install a dedicated synchrotron radiation beamline at CAMD for the SEA. A brief summary of the currently funded projects follows. 


\section{PROGRAM SUMMARIES}

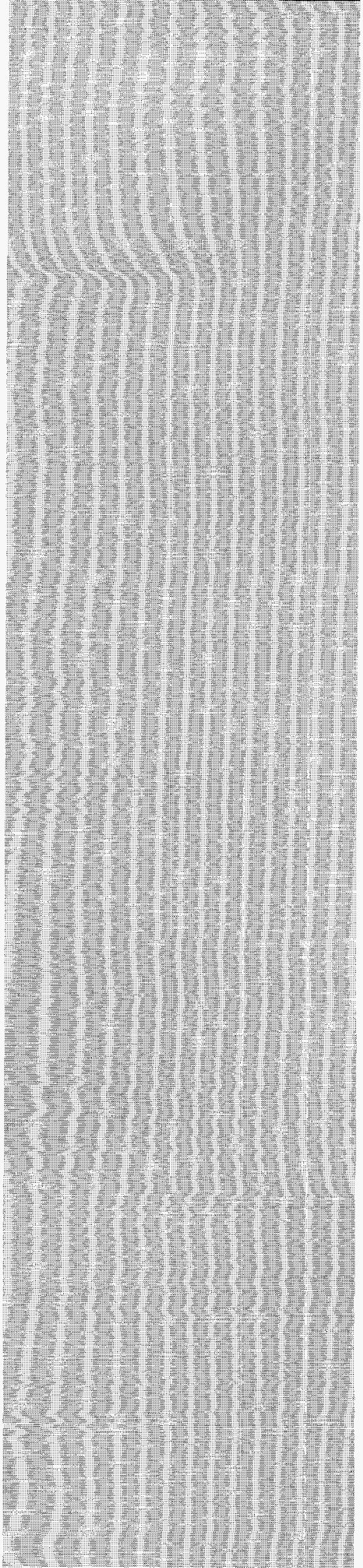

CAMD

\title{
Structural Studies of Solid Polymer Electrolytes and Intercalation Cathode Materials of Solid State Batteries
}

PIs: Rambabu Bobba a, P.M. Lam ${ }^{a}$, T.H. Wang ${ }^{a}$, P.J. Schilling ${ }^{b}$ Institutions: aSouthern University and A\&M College

bLouisiana State University

rambabu@stark.phys.subr.edu

The primary goal of this effort is to explore new and improved ionic conductors and mixed conducting materials for lithium batteries. EXAFS and XANES, using synchrotron radiation, has permitted the in situ study of electrochemical systems and to probe structural changes of materials during charge/discharge cycles.

\section{Accelerated Illumination of Fluorinated Amorphous Silicon}

\author{
PIs: Hylton G. McWhinney, T.N. Fogerty, R. Wilkins \\ Institution: Prairie View A\&M University \\ hmcwhin@diamond.pvsci.pvamu.edu
}

Fluorinated amorphous silicon films are prepared from silane and fluorine sources using plasma-assisted vapor deposition. Such materials are of interest in photovoltaic applications. The long term stability of these materials must be established in order to determine their potential for devices. A high intensity solar simulator using synchrotron radiation will allow the determination of stability under radiation to be established for these materials. Also, structural changes due to exposure will be explored. 


\section{High Resolution X-ray Imaging Experiments}

PIs: Paul J. Eberta, Daniel J. Dietrich ${ }^{b}$

Institutions: aNOLASCO-Science Consultants

bLawrence Livermore National Laboratory

pjenolasco@aol.com

The development of an X-ray microscope will open a broader areas of scientific study, including intracellular imaging. This research is involved in studying the $X$-ray optical properties of opaque spheres and etched nuclear particle tracks. Synchrotron radiation is a convenient, intense $\mathrm{X}$-ray source for magnification.

\section{Materials for Photolithography and Other Photopatterning Applications}

PI: Robert Gooden

Institution: Southern University and A\&M College rtgooden@aol.com

As features for microelectronic circuits continue to shrink, new materials must be developed to produce the increasingly smaller devices. Deep UV (below $200 \mathrm{~nm}$ ) photolithography appears to be the choice for the next stage of microcircuit fabrication. This project will explore materials of utility in lithography, such as photoresists and alignment aids. Synchrotron radiation is a most versatile source of intense deep UV radiation for fundamental studies of the patterning properties materials.

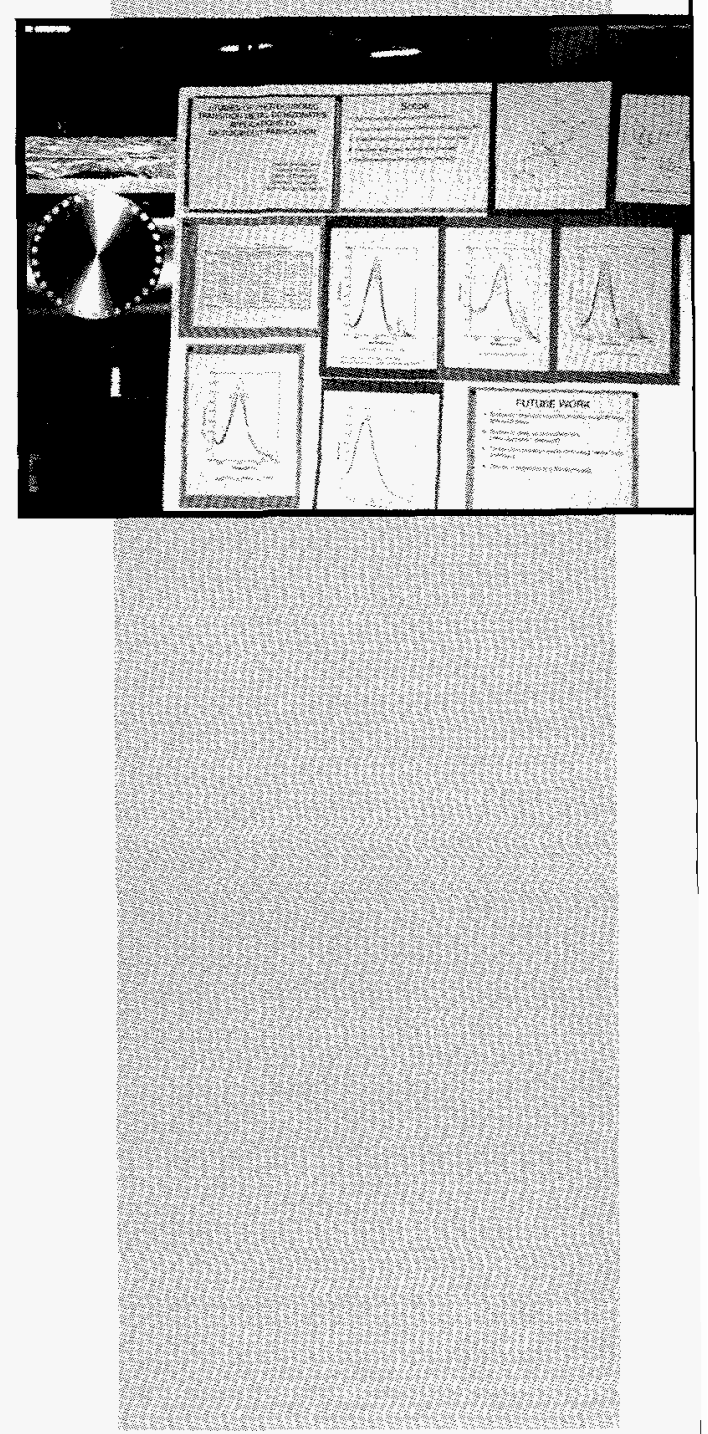




\section{PROGRAM SUMMARIES}

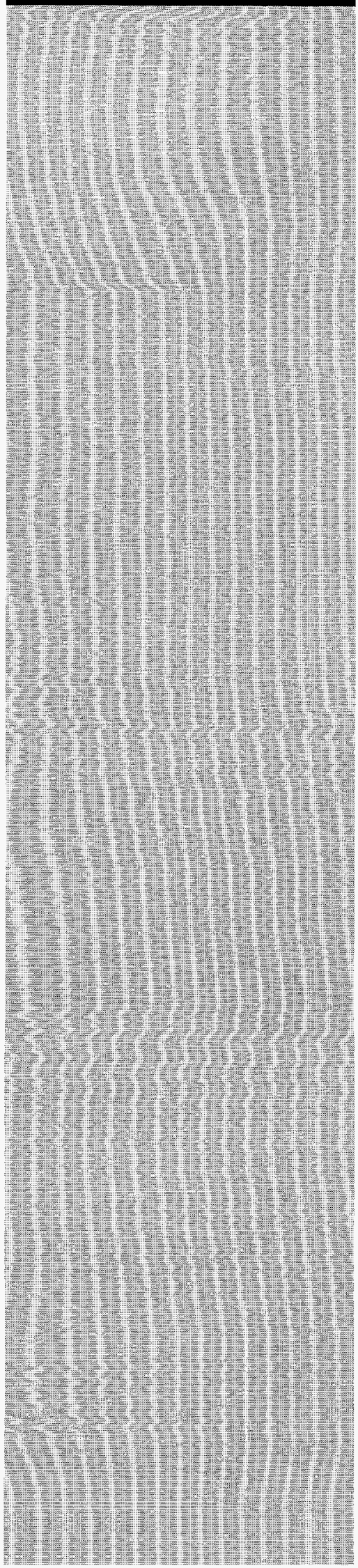

CAMD

\section{EXAFS Analysis of Sulfur K-edge in Rock- Forming Minerals--Greenochkite, Chalcopyrite and Stannite}

PI: Innocent Aluka

Institution: Prairie View A\&M University

Crystalline and glassy minerals are found in West Texas rocks reflecting geological orgins of upper mantle magma. The elemental and structural content of these rocks is facilitated using EXAFS and other X-ray diagnostic methods. This project involves both field sample collection and laboratory analysis, primarily at CAMD.

\section{Investigations of Synchrotron Radiation Irradiated Surfaces and Interfaces in MOS Structures}

PIs: Pradeep K. Bhattacharya, J.A. Anderson, A. Singh

Institution: Southern University and A\&M College

Bhattach@cluster.engr.subr.edu

This project focuses on the investigation of the annealing of metal oxide semiconductor structures, the interfacial diagnostics of virgin, $X$-ray and process-induced damaged gate oxides, and a study of $X$-ray synchrotron radiation effects on metal oxide field effect transistors. 


\section{The Small Business Technology Transfer (STTR) Program}

\section{Introduction}

The Small Business Technology Transfer (STTR) pilot program awards contracts to small business concerns for cooperative research and development with a research institution through a uniform, three-phase process. STTR, though modeled after the Small Business Innovation Research (SBIR) program, it differs from SBIR in several aspects.

Unlike SBIR:

- Universities, Federally Funded Research and Development Centers (FFRDCs), and non-profits can participate in the STTR program.

- Principal Investigators (PIs) are not required to be employed by the small business concern.

- STTR initiatives are directed to private sector, with Phases I and II being product development oriented, and Phase III commercialization oriented.

Phase I projects identify the merit and feasibility of the idea. Phase II projects demonstrates that the idea works and has promise. Phase III projects continues in pursuit of full commercialization. Phases I and II are funded by NASA at an upper limit of $\$ 100,000$ and $\$ 500,000$ respectively. Phase III is supported by private funding.

In 1996, NASA's Office of Space Access and Technology funded an SEA initiative through its STTR pilot program. SEA member, Alabama A\&M University (AAMU), teamed with Systems 


\section{PROGRAM SUMMARIES}

\section{STTR}

Engineering and Management Associates, Inc. (SEMA) of Alexandria, Virginia, on a Phase I project. Following peer review, the STTR Phase I initiative was funded by NASA for one-year at a funding level of $\$ 100,000$. SEMA serves as the Small Business Concern (SBC) and AAMU the Research Institution (RI).

\section{Synthetic Simultaneity: A Teleoperations Method for Remote Control of Extremely Distant Vehicles}

Co-PIs: John Caulfielda, Marius Schamschula ${ }^{a}, B^{2}$ Consilvio ${ }^{b}$ Institutions: a Alabama A\&M University,

bSystems Engineering and Management Associates

hjc@dubois.fisk.edu

marius@caos.aamu.edu

ben_consilvio@semainc.com

To operate a rover on another planet such as Mars is a problem. The problem is compounded by time delays of 30 minutes to almost two hours. It is helpful to assist an operator by giving views projected forward in time. In the case of a Mars rover, this might be tens of minutes. A Mars rover does not operate blindly. The overall route is planned using catography derived from orbiter photographs. These maps have a resolution on the order of meters, not good enough to make proper route planning decisions. Routes, however, are designed this way for the present mission to Mars. The rover relies on its onboard cameras and computer to make adjustments for obstacles. The pattern recognition and processing power of a rover is limited, and often there is no rule in the control algorithm for a given situation. This is the situation where a human must be in the loop. 
In this project, the researchers have developed a Synthetic Simultaneity paradigm as a way of involving a human operator. It takes orbiter cartography to establish a rough terrain database, augments this database with pictures from the rover, and then uses the terrain database to forward project the rover's position in time and render a 3-D scene for the operator.

\section{During NASA's 1996 Inspection Day at Johnson Space Center}

(JSC) in Houston, TX, the SEA/SEMA researchers demonstrated the issues involved in operating a robot or rover with time delayed video. Using a pair of Connectix QuickCam digital cameras for the display, the researchers introduced a time delay of about a second. This is similar to one expected for a Moon rover. The relatively low frame rate produced by these cameras is also indicative of a problem caused by low transmitter power of a Mars rover. The rover used in the Inspection Day was a toy, but the pictures and digital movies showed a number of problems faced by an autonomous rover. These include shadows, concave shapes, horizon lines, etc. The group also displayed a mock-up of the operator console.

For more information, please visit our web site:

http:/www.caos.aamu.edu/ marius/SySim.html. It displays some 3-D rendered "Synthetic" Martian terrain, both as still photographs and as a QuickTime movie. 


\section{PROGRAM SUMMARIES}

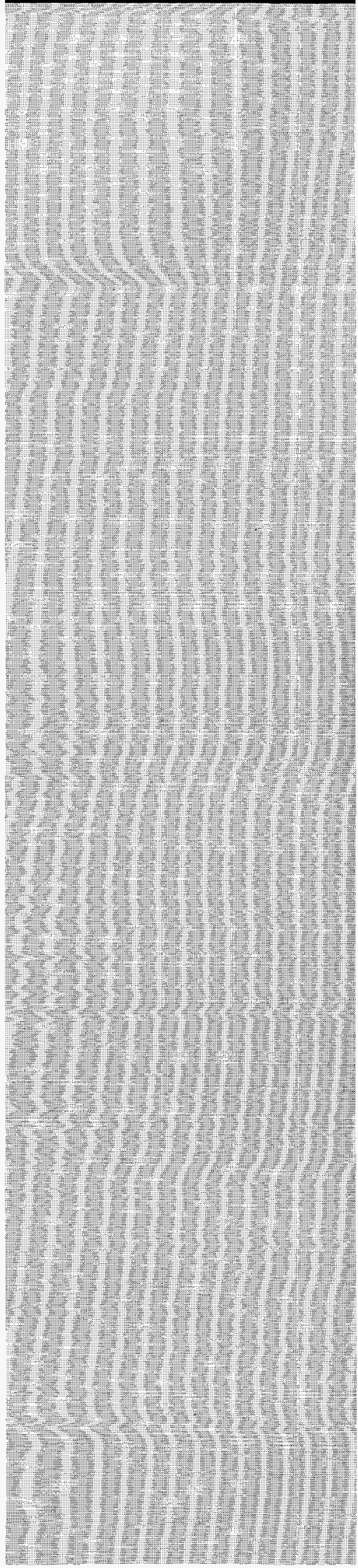

\section{CEJAT}

\section{Community Environmental Justice Awareness Training (CEJAT) Project}

Co-PIs: Connie Wilson-Jordan ${ }^{\mathrm{a}}$, Bennie Henderson ${ }^{\mathrm{b}}$, John Williams ${ }^{\mathrm{C}}$, Robert Ford ${ }^{\mathrm{d}}$

Institutions: a Alabama A\&M University, ${ }^{\mathrm{b}}$ Jackson State University, CPrairie View A\&M University, $\mathrm{d}_{\text {Southern }}$ University and A\&M College cwilson@asnaam.aamu.edu, bhend@stallion.jsums.edu, John_r_williams@pvamu.edu, robert.ford@em.doe.gov

The Community Environmental Justice Awareness Training (CEJAT) project is a multi-state community environmental justice and empowerment initiative. Objectives of the project include:

- Identification of target low-income and minority communities in Huntsville, AL (AAMU), Jackson, MS (JSU), Prairie View, TX (PVAMU), and Baton Rouge, LA (SUBR);

- Conducting environmental justice town meetings clesigned to bring a greater awareness of environmental health issues to the local communities;

- Conducting train-the-trainer workshops for community groups; and

- Introducing community residents to Geographical Information System (GIS) and other technology tools for assessing current conditions and planning strategies for mitigating disparate community impacts. 
Additionally, through CEJAT, the SEA examines the environmental justice movement in the United States and the role of Historically Black Colleges and Universities (HBCUs) in assuring environmental justice and community empowerment in Black communities. CEJAT was supported by the EPA at an initial funding level of $\$ 200,000$.

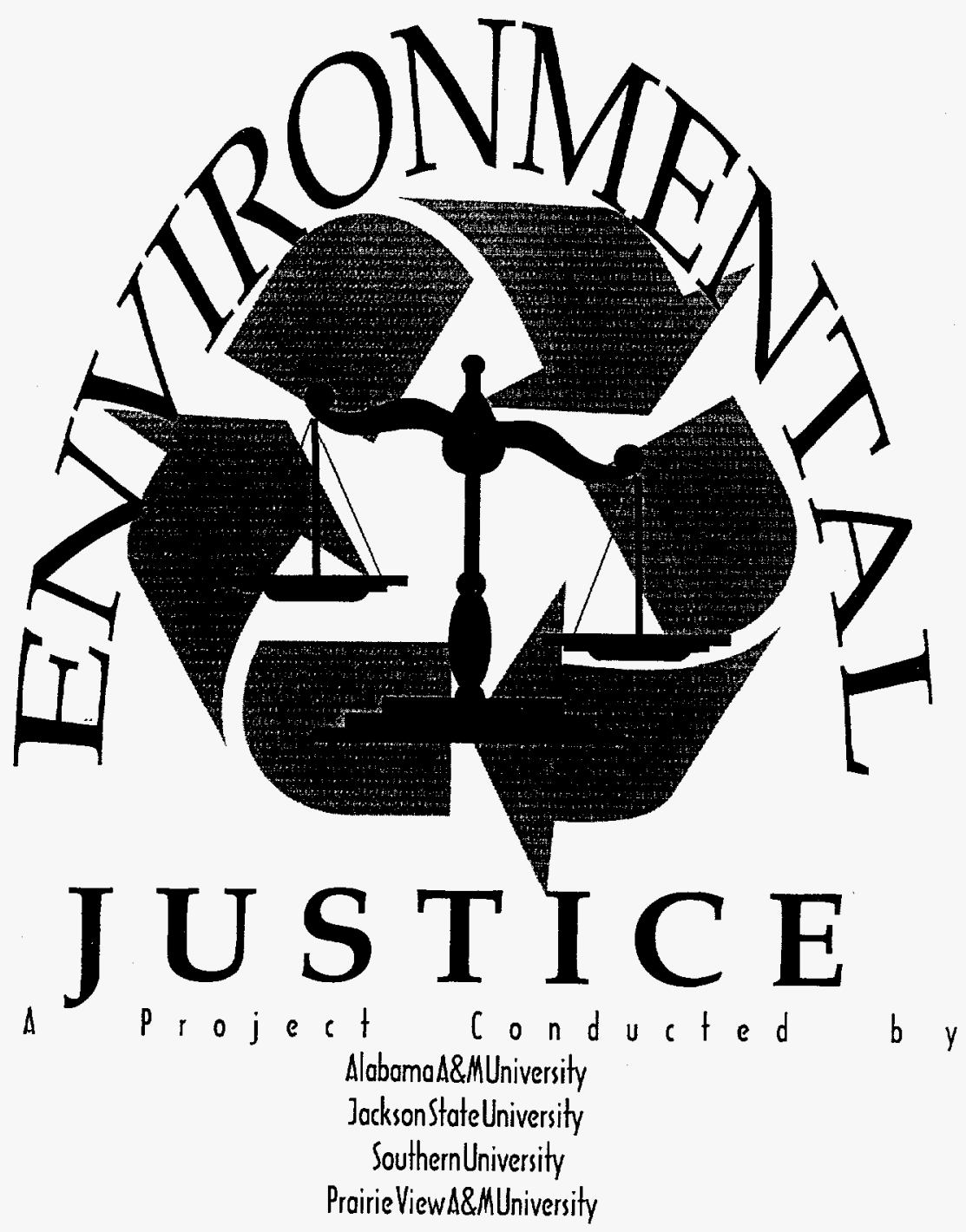




\section{High School Teacher Enhancement in the Sciences}

Co-PIs: Abdul Mohamed ${ }^{a}$ and Robert L. Shepard ${ }^{b}$

Institutions: aJackson State University and bSEA Headquarters

mohamed@stallion.jsums.edu,

rshepsea@aol.com

As part of an effort to improve the teaching of science in a fourState region (Alabama, Mississippi, Louisiana, and Texas), the Science and Engineering Alliance (SEA) initiated a series of teacher enhancement workshops in science. The workshops focus on problem solving through experience gained in laboratory, field work, classroom discussions and interactions/debates, critical analysis of the literature, appreciation of the application of mathematics in science, and interactions with experts in various fields of science.

The project lead to development of the "Science Resource Guide - Teaching Science In the 21st Century." This reference was developed to assist the novice and experienced teachers. The Guide incorporates practical applications of comtemporary science education reform and strategies. The Guide was prepared under the direction of the Southern University's Project Director for the SEA Funds for the Improvement of Postsecondary Education (FIPSE) project, with input from workshop participants and other high school science teachers.

The Guide was reviewed by education specialists from Southern University and Louisiana State University. The Resource Guide is "teacher friendly." 


\section{Scientific Awareness Workshop for Culturally Diverse Colleges and Universities}

PIs: Robert L. Shepard

Science and Engineering Alliance Headquarters

rshepsea@aol.com

On April 22-23, 1996, the Science and Engineering Alliance (SEA) conducted a scientific awareness workshop for 20 small and rural, United Negro College Fund (UNCF) Historically Black Colleges and Universities (HBCUs). The workshop was held on the campus of Saint Augustine's College in Raleigh, NC. The workshop opened with presentations by EPA administrators, Dr. Robert Huggett, Assistant Administrator for EPA's Office of Research and Development, and Mr. Timothy Fields, Deputy Assistant Administrator for EPA's Office of Solid Waste \& Emergency Response. The two speakers described EPA's expectations of excellence from academic institutions involved in Agency funded projects. Included in their presentations was an overview of the eight (8) high priority technical areas of concern and interest to EPA. Mr. Clyde Bishop, Environmental Scientist, EPA, provided additional technical details on EPA's program.

The initial task was to conduct a workshop for science faculty members and individual identified as the institution's Federal Grants Officer. The purpose of this initial phase was twofold:

1. To acquaint the participants with the methods, procedures and techniques for securing scientific grants, individually and through cooperative partnerships; and

2. Establish an annual workshop on preparing grants and and cooperative agreements in support of EPA's technical mission.

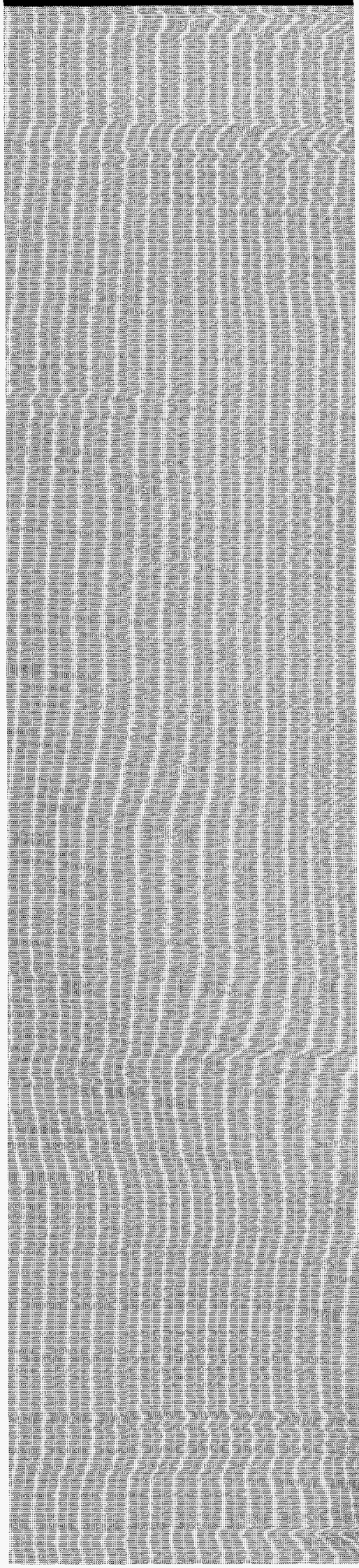



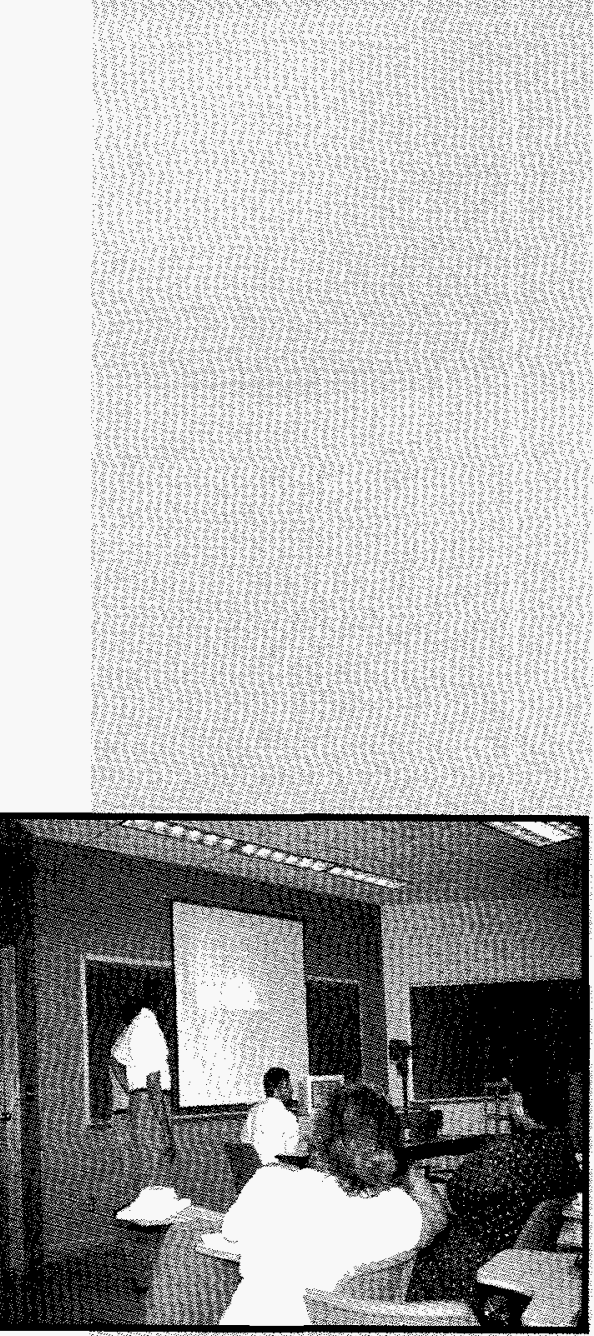

\section{TECHNICAL ASSISTANCE}

The lessons learned as a result of the workshop include:

1. Rather than developing proposals in the initial workshop, identify the capability and interest of each participant and their institution. Once this is completed, develop collaborative proposals for submission to EPA.

2. The SEA Project Team should not rely totally on the baseline survey data to establish partnerships among the participants. Participant input revealed that some institutions have developed strong non-technical working relationships at the president-to-president level. Participants believe that when possible, existing executive relationships should be the basis for developing technical partnerships. They noted that relationships at this level shows institutional committment to the effort.

3. New program initiatives in technical areas like environmental science, environmental justice, etc., are underway at some institutions. These activities should be factored into the workshop proposal development strategy.

4. A need to re-convene the participants and factor in Items 1, 2, and 3 above, and proceed to develop partnerships among schools and complete collaborative proposals for submission to EPA.

5. Some institutions are not linked to the government's FEDIX/MOLIS nor MUSPIN databases. 


\section{APPENDICES}

1. Executive Summary from High School Teacher Enhancement Workshops held during the summer at each of the SEA institutions.

2. Executive Summary from the Scientific Awareness Workshop for Culturally Diverse Colleges and Universities.

3. Evaluation of Distant Learning Course in Molecular Biology.

4. Listing of new collaborations between LLNL technical staff and SEA faculty and students. The new projects resulted from experience gained by SEA faculty and students while participating in summer research program at LLNL.

5. Listing of the 150 SEA undergraduate scholarship and high school incentive award recipients.

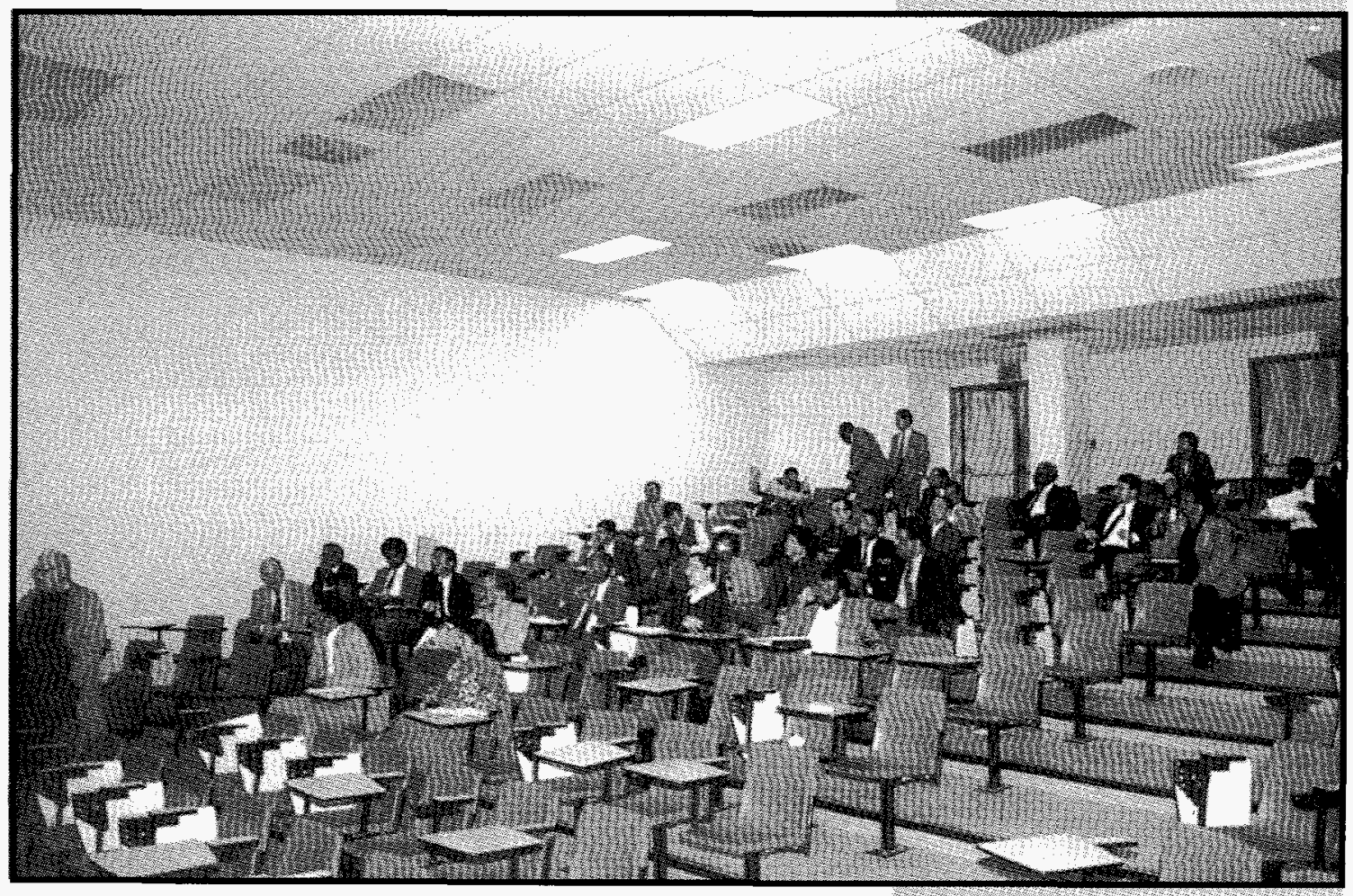


P116B11969

\title{
HIGH SCHOOL TEACHER ENHANCEMENT IN THE SCIENCES
}

\author{
Science and Engineering Alliance, Inc. \\ 1522 K Street, N.W. \\ Suite 210 \\ Washington, DC 20005 \\ Robert L. Shepard, Ph.D. \\ 202/842-0388
}

EXECUTIVE SUMMARY

\section{Project Overview}

As part of an effort to improve the teaching of science in a four-State region (Alabama, Mississippi, Louisiana, and Texas), the Science and Engineering Alliance (SEA) initiated a series of teacher enhancement workshops in science. The workshops focus on teaching problem solving through experience gained in laboratory, field work, classroom discussions and interactions/debates, critical analysis of the literature, obtaining a greater appreciation of the application of mathematics in science, and interactions with experts in various fields of science.

Fund for the Improvement of Postsecondary Education (FIPSE) funded the workshops. The U.S. Department of Energy's (DOE) Office of Science and University Education supplied some funds to augment the FIPSE support.

The SEA member institutions hosting the workshops were Alabama
A\&M University (Normal, AL), Jackson State University (Jackson, MS), Prairie View A\&M University (Prairie View, TX), and Southern University and A\&M College (Baton Rouge, LA).

\section{Background, Origin, and Purpose}

The general belief is that the U.S. educational system needs to be strengthened. To remain competitive requires an educated public that is aware of the basic concepts upon which technology is built. The system must also be capable of producing scientists and engineers that can contribute to the technological competitiveness of the nation.

According to studies reported on by the National Science Foundation (NSF), the teachers' educational background, specifically whether they have an undergraduate or a graduate major in the field of 
instruction, is the most widely used indicator of a teachers' understanding of and expertise in their field (NSF, Science \& Engineering Indicators -- 1996). Thus, it is widely accepted that teacher competence is related to subject matter knowledge.

The SEA supports these conclusions, and thus, developed a series of summer science enhancement workshops to strengthen high school teachers that are teaching science and mathematics in high schools in the four-State region.

Therefore, the impetus for the workshops was:

- The charged environment that surrounds the issues pertaining to the serious deficiency in the U.S. educational system in all academic disciplines; and

- A natural extension of the partnership that exist between the SEA institutions and the $\mathrm{K}-12$ school districts in various regions within the four-State region.

The workshops focused on teaching problem solving through a variety of means. This included experience gained in laboratory, field work, classroom discussions and interactions/debates, critical analysis of the literature, gaining a greater appreciation of the application of mathematics in science, and interaction with experts in various fields of science.

\section{Project Description}

The workshops covered physical, biological, and earth sciences. To assess the impact of the workshops, the same $80+$ teachers that participated in the initial sessions were involved throughout the program.

The workshops used SEA faculty from the departments of biology, physics, mathematics, chemistry, environmental science, earth science and physical science. The SEA faculty members worked directly with the high school science and mathematics teachers. In addition, technical experts from Lawrence Livermore National Laboratory (LLNL) conducted several of the workshops, lectures, and demonstrations for the high school teachers.

The workshop format included lecture/discussions and exploration/ laboratory demonstrations, and were coordinated by an SEA faculty member and two workshop participants designated as lead teachers. Lead teachers were identified for each of the three areas, i.e., a lead teacher for physical science, one for biological science, and another for earth science. Lead teachers assisted in facilitating and coordinating workshop activities.

Also, lead teachers were tasked with holding mini-discussions for 
their fellow teachers who did not participate in the workshops. The lead teachers were selected based on the relative strengths of their application and recommen-dations. Additional lead teachers were chosen over the next two years based on the outstanding leadership ability these teachers displayed. in the initial workshops.

\section{Evaluation: What Worked and Did} not Work

The SEA used an evaluation team comprised of experts from SEA institutions' Department of Education. The evaluation team assessed the impact of the workshops at the campus level and the collective impact of the total SEA workshop project on a regional basis. The collective responses to the evaluations were overwhelmingly high, ranging from an average of $88 \%$ $100 \%$ for each instrument.

Following the 1994 workshops, administrators from the four-State region were asked to do a qualitative assessment of the science and mathematics activities at their school. Principals and counselors indicated that while it was too early to assess the full impact on student test scores, they all witnessed greater enthusiasm toward science and mathematics on the part of both the students and teachers. This was an indication the Workshops were of some value.

Impact or Changes from Grant Activities
Five years following the initial funding by FIPSE and DOE, the SEA continues to seek additional support to continue and institutionalize the summer workshops. According to the studies on teacher qualifications, it appears that the workshops are still necessary. The workshops are a good investment.

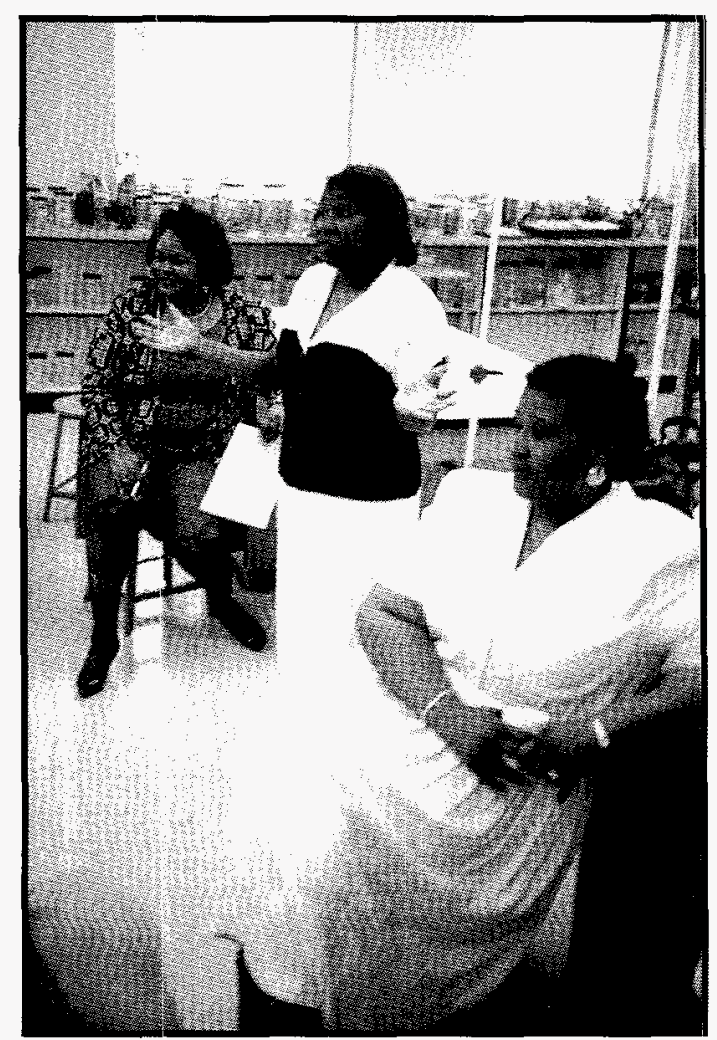

\section{Progress Since the Grant Ended}

This project lead to the development of the "Science Resource Guide - Teaching Science In the 21st Century." This reference was developed to assist the novice, reassigned and experienced instructor of high school science with practical applications of contemporary science education re- 
form and strategies. The Guide was prepared under the direction of the Southern University's Project Director for the SEA FIPSE project, with input from participants in our workshops and other high school science teachers.

HIGH SCHOOL TEACHERS ENHANCEMENT IN SCIENCES

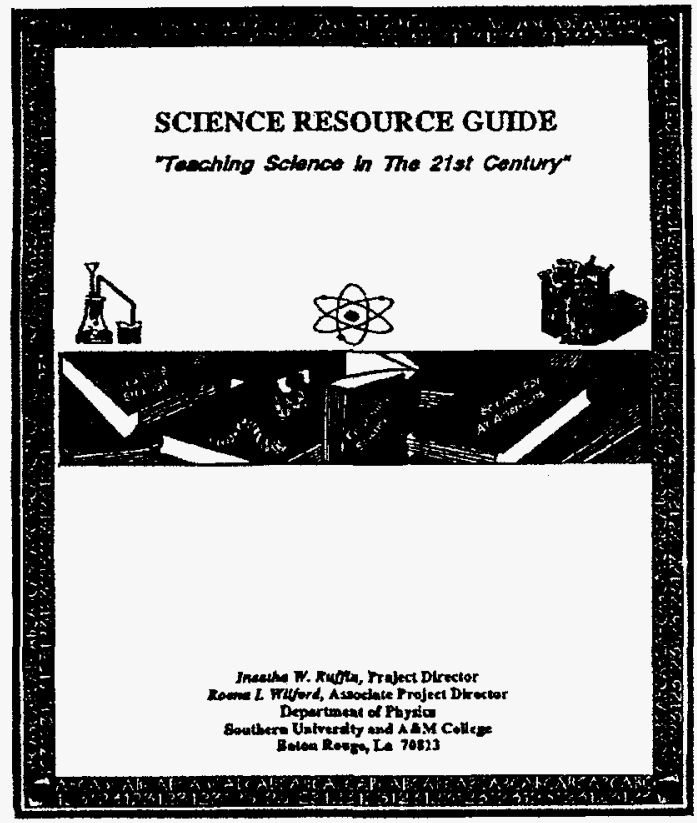

The Guide was reviewed by education specialists from Southern University and Louisiana State University. The Resource Guide is "teacher friendly." A complimentary copy of the Resource Guide was provided to each of the participants of the High School Teachers Enhancements in Science Workshops (1992-1995) and to selected schools located in the rural parishes of the State of Louisiana.

The schools selected to received a copy of the Resource Guide was based on an article that appeared in the Baton Rouge Newspaper (Morning Advocate) on July 30,
1995, listing each parish and the number of faculty not certified. Eleven parishes with the highest percent uncertified teachers were sent serveral copies of the Guide. Written permission was given to them to make copies of the guide for their use. High school science teachers outside of the 11 parishes have seen the Guide and have requested and received a copy.

The teachers have indicated that the Guide is very informative, the activities included in the Guide have been useful in the classroom, and have given them ideas about additional activities.

The other SEA locations in the other three States are expected to use the Resource Guide to produce a similar resource for their region. Copies of the Resource Guide may be requested from:

Ineatha W. Ruffin

Department of Physics

Southern University and A\&M College

Baton Rouge, LA 70813

504/771-4130 


\title{
Scientific Awareness Workshop for Culturally Diversed Colleges and Universities
}

\author{
EXECUTIVE SUMMARY
}

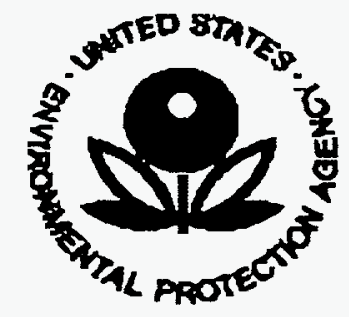

Preliminary Report

\section{Scientific}

Awareness

Workshop

for Culturally

Diversed Colleges

and Universities

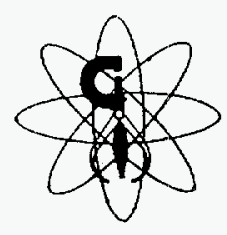

SEA Workshop Team

Science and Engineering Alliance, Inc. o The Science and Engineering Alliance (SEA) conducted Phase I of a scientific awareness workshop for 20 small and rural Historical Black Colleges and Universities (HBCUs) on the campus of Saint Augustine's College in Raleigh, North Carolina.

A total of thirty (30) HBCU science faculty and administrators participated in the workshop. Of the 30 participants, 19 were science faculty, 11 were personnel responsible for grant administration/sponsored programs, and one representative for the United Negro College Fund (UNCF). The science faculty represented Physics, Chemistry, Biology, Molecular Biology, Ecological Science Education, and Environmental Science.

Based on preliminary assessment of a few of the participants' surveys, some of the institutions are in various stages of developing new programs and curricula. For example, because of being located some 45 miles east of DOE's Savannah River Plant, Voorhees College in South Carolina is instituting a new Minor in Environmental Science. Additionally, other institutions are concerned about environmental protection in the low income, minority communities they serve. Several of the participants expressed a desire to use the SEA workshop to help them develop focused, community-based programs in the area called environmental justice. Therefore, when developing the partnership proposals, the SEA will examine EPA's Office of Sustainable Ecosysterns and Communities' (OSEC) report entitled " $A n$ Assessment of EPA Regional Offices' Community-Based Environmental Protection Needs," to look for ways of incorporating the experience and working relationships that HBCUs have with their communities to address the needs and concerns raised in OSEC's report. 
o Participants were satisfied with elements of the workshop and the practical information they can use in their work.

Some participants were knowledgeable of methods, procedures, and techniques for securing scientifically related grants from EPA and other federal agencies. Most were not knowledgeable of the high priority technical areas of interest and concern to the EPA. The majority of participants rated the workshop very high based on the contents meeting their expectation, and ultimately being of use in their work. Most rated the portion of the workshop on how to obtain up-to-date information on various agency initiatives via the Internet as highly useful, especially the two Internet addresses the SEA provided for accessing all of the federal agencies listed on the Internet: http://www.lib.lsu.edu/gov/fedgov.html and http:lcweb.loc.gov/global/executive/general resources.html.

Several participants indicated the need to have the SEA organize similar workshops at the campus level for interested science faculty who could not attend the workshop in North Carolina. In the interim, participants spoke of the many useful ideas about grantsmanship they would take back to share with those science faculty that were not able to attend the workshop. Some participants stressed the need for the SEA to conduct broader-based workshops that would include NIH and other federal agencies.

o HBCU science faculty are positive to the idea of collaborations and partnerships.

Nearly all of the participants were in favor of developing partnerships and collaborations among themselves, with the SEA institutions, and with major universities. They viewed collaborations and partnerships as effective approaches to seeking grant support from the EPA. Some expressed the view that the Phase I workshop should have devoted time to actually developing the first draft pro-posals on projects of interest to the parti-cipants, and forming possible partnerships among the institutions represented. Some participants shared the difficulty of perform-ing undergraduate research because of lack of funding and facilities. The core idea of colla- borations and partnerships was viewed as the answer to the problems of limited funds and facilities.

o Participants need training, technical assistant, information, mentors, and other resources.

Participants expressed concern that some science faculty still may not understand how to develop their work into a competitive proposal. Thus, it was suggested that during Phase II the SEA consider assigning a project to small groups for them to develop a "mock" proposal. Additionally, it was expressed that in subsequent workshops that the SEA focus on providing in-depth information regarding what the institutions should do once a grant is funded. Training was requested on preparing proposals for future funding of projects that have received initial seed funding. Some participants are in the process of searching for mentors to establish research collaborations and viewed the work-shop as another resource.

o Science faculty need to better expose their individual capability and their institution's as well.

Most of the participants' individual nor institutional capability information is part of the Federal Information Exchange/Minority On-Line Information System (FEDIX/ MOLIS) computer database. Nor is this information a part of the Fedix Alert Profile communications and connectivity database. Some have included their institutional information in the federal Minority University Space Interdisciplinary Network (MUSPIN) database. Participants requested the SEA with supporting the incorporation of their information into these federal databases.

For information on workshop evaluation and letters from participants, see the Appendix. 


\section{Scientific Awareness Training Workshop Participants}

W.A. Funderbuck

Physical Science

Benedict College

Harding \& Blanding Street

Columbia, SC 29204

(803) 253-5165

Carol A.L. Meeks

Director of Grants

Livingston College

701 West Monroe Street

Salisbury, NC 28144

(704) 638-5710

(704) 638-5667 (Fax)

James L. Mack

Chemistry Dept.

Fort Valley State College

Fort Valley, GA 31030

(912) 825-6245

(912) 825-6104 (Fax)

jmack@fvs3.fvsc.peachnet.edu (e-mail)

John Elwood

Chemistry

Claflin College

700 College Avenue

Orangeburg, SC 29115

(803) 535-5242

(803) 531-2860 (Fax)

JELWOOD@scsu.scsu.edu (e-mail)

Krishna Puttaparthi

Asst. Prof. of Biology

Jarvis Christian College

P.O. Drawer G

Hawkins, TX 75765

(903) 769-5807

(903) 769-4842 (Fax)
Fouzi Arammash

Physics

Benedict College

Harding \& Blanding Street

Columbia, SC 29204

(803) 253-5273

Bianca L Graves

Asst. Prof. of Biology

Livingston College

701 West Monroe Street

Salisbury, NC 28144

(704) 638-5431

bgraves@stone1.1sc.edu (e-mail)

Dan Durett

UNCF

8260 Willow Oak Corp. Drive

Fairfax, VA 22031

(703) 205-3462

(703) 205-3574 (Fax)

Bassey A. Eyo

Dept. of Biology

Claflin College

700 College Avenue

Orangeburg, SC 29115

(803) 535-5223

Ronnie Wright

Director of Sponsored Programs

Jarvis Christian College

P.O. Drawer G

Hawkins, TX 75765

(903) 769-5800

(903) 769-4842 (Fax)

rwright@gower.net (e-mail) 
Philip W. Archer Dept. of Biology

Virginia Union University

1500 N. Lombardy Street

Richmond, VA 23220

(804) 257-5613

(804) 257-5629 (Fax)

Delbert R. Buffinger

Natural Science

Wilberforce University

1066 N. Bickett Road

Wilberforce, $\mathrm{OH} 45384$

(513) 376-2911 ext. 639

Francis L. A. Buckmire

Dept. of Biology

Bennett College

900 E. Washington Street

Greensboro, NC 27401

(910) 370-8641

(910) 370-8665 (Science Biology)

Marilyn Semtner

Botany; Aquatic Sci.

Saint Paul's College

406 Windsor Avenue

Lawrenceville, VA 23868

(804) 848-3111

Thomas C. McCain

Math Education

Voorhees College

1411 Voorhees Road

Denmark, SC 29042

(803) 793-3351

(803) 793-4584 (Fax)
Harry S. Bass

Dept. of Biology

Virginia Union University

1500 N. Lombardy Street

Richmond, VA 23220

(804) 257- 5612

(804) 257- 5627

hbass@cabell.vcu.edu. (e-mail)

Maha Nagarajan

Molecular Biology

Wilberforce University

1066 N. Bickett Road

Wilberforce, $\mathrm{OH} 45384$

mnagaraj@wv.wilberforce.edu

Shingara S. Sandhu

Director Research/Grants

Claflin College

700 College Avenue

Orangeburg, SC 29115

(803) 535-5244

(803) 531-2860 (Fax)

ssandho@scsu.scsu.edu (e-mail)

Clyde Bishop

Environmental Scientist

U.S. EPA

401 M Street, SW

Washington, DC 20460

(202) $260-5727$

(202) 260-0211 (Fax)

bishop.clyde@epamail.epa.gov

Jennie L. Stephens

Dir. of Sponsored Programs

Voorhees College

1411 Voorhees Road

Denmark, SC 29042

(803) 793-3351

(803) 793- 4584 (Fax) 
Moges Abebe

St. Augustine's College

1315 Oakwood Avenue

Raleigh, NC 27610

(919) 516-4030

maebe@fsi.st-aug.edu (email)

Robert Huggett

Assistant Administrator

U.S. EPA

Office Researh \& Development

401 M Street, SW

Washington, DC 20460

(202) 260-7676

Derrick C. Tabor

Associate Professor

Johnson C. Smith University

100 Beatties Ford Road

Charlotte, NC 28216

(704) 378-1059

(704) 378-1050 (Fax)

Stanley W. Johnson

Director of Sponsored Programs

Saint Paul's College

115 College Drive

Lawrenceville, VA 23868

(804) 848-0068

(804) 848-0816 (Fax)

Wilease Sanders

Director of Sponsored Programs

Benedict College

1600 Harding Street

Columbia, SC 29204

(803) 253-5427

(803) 253-5194 (Fax)
Selma T.T. Burrell

Div. of Natural Science

Barber-Scotia College

145 Cabarrus Avenue, West

Concord, NC 28025

(704) 793-4975

(704) 529-6608 (Fax)

Timothy Fields, Jr.

Deputy Assistant Administrator

U.S. EPA

Office of Solid Waste \&

Emergency Response

401 M Street, SW

Washington, DC 20460

(202) $260-4610$

Ronnie Wright

Director, Sponsor Program

Jarvis Christian College

P.O. Box Drawer G

Hawkins, TX 75765

(903) $769-5700$

(903) 769-4842 (Fax)

(903) 769-5800

rwright@gower.net (e-mail)

Janice Burkes

Title III Coordinator

Bennett College

900 E. Washington Street

Greensboro, NC 27401

(910) $370-8659$

(910) 370-8733 (Fax)

Larry Thompson

Associate Professor

Johnson C. Smith University

100 Beatties Ford Road

Charlotte, NC 28216

(704) 378-1298 


\section{Scientific Awareness Training Workshop \\ Workshop Leaders}

\section{Workshop Site Coordinator}

Wiley M. Davis

Saint Augustine's College

1315 Oakwood Drive

Raleigh, NC 27610

(919) $516-4200$

(919) 516-4482

(919) 828-0817 (Fax)

\section{The SEA Workshop Team}

Robert W. Taylor

Alabama A\&M University

P.O. Box 1208

Normal, AL 35762

(205) 851-5462

(205) 851- 5429 (Fax)

Shelton Swanier

Jackson State University

1400 J.R. Lynch Street

Jackson, MS 39217

(601) $968-2313$

(601) 968-2718 (Fax)

John R. Williams

Prairie View A\&M University

P.O. Box 2576

Prairie View, TX 77446

(409) 857-3910

(409) 857-2095 (Fax)

Robert L. Ford

Southern University A\&M Coll.

P.O. Box 9764

Baton Rouge, LA 70813

(504) 771-4724

(504) 771-4722 (Fax)

\section{Workshop Leader}

Robert L. Shepard

Executive Director

Science and Engineering Alliance, Inc.

1522 K Street, NW, Suite 210

Washington, DC 20005

(202) 842-0388

(202) 842-0403 (Fax) 


\title{
SEA's Distant Learning Course in Modern Molecular Biology
}

\author{
Evaluation of Phase 1
}

July 25, 1996

\author{
Course Title: \\ Special Topics in Modern Molecular Biology \\ Time: \\ 1:00 PM - 2:00 PM -- Monday, Wednesday, \\ Friday (Spring 1996) \\ Participants: $\quad$ AAMU -- 11 Students \\ JSU -- 19 Students \\ PVAMU -6 Students \\ SUBR -- 14 Students \\ Author: \\ Robert L. Shepard, Ph.D., Executive Director, SEA
}

Background: Three platforms were used to implement Phase 1 of the SEA distant learning course. These included (1) chat sessions across the Internet (included transmission of Power Point vu graphs), (2) video taping, and (3) televideoconferencing.

A course syllabus was developed for the course. Since four different institutions were involved in the design of the course, each institution was required to participate in a joint meeting to develop the detailed syllabus. This was necessary to assure that the course would meet the needs of all students. The course:

1. Was offered to senior level undergraduates and graduate students as a 3 credit course.

2. Lasted 16 weeks, and was taught 3 hours each week.

3. Offered the same time on all four SEA campuses. Time difference of Lawrence Livermore National Laboratory in the Pacific Time Zone was taken into consideration.

4. Will consist of $33 \%$ chat sessions using America on Line $($, $33 \%$ video tapes, and $33 \%$ televideoconferencing. Thus, each institution was required to produce 4 video tapes.

5. Final exam was in one common central area for all the students, probably right after the regular semester final exams. Students will also present papers at this time, and get to meet each other. Students will receive certificates.
6. Students were taught how to use the Internet, and some of the assignments taught them how to find information on the Internet. Assignments were sent to students via E-mail.

7. Each institution should invest in a $\$ 300$ "See you, See me" camera on desk top and software to be used for office hours.

Outcome: Most of the course objectives were met. However, two activities were not implemented during Phase 1 . These were the televideoconferencing portion and bringing the students together to take their final exam and meet each other face to face. Relative to the final exam, students were given a standard type exam at their respective location using the information disseminated in the course.

Identification of Problem(s) Needing Support: Relative to televideoconferencing, it was detected that a Multi-point Control Unit (MCU) was required in order to conduct fourway televideoconferencing. The schools, and LLNL, were limited to only point-to-point connection resulting in only one location interacting via televideoconferencing at any one time. The VTEL systems located at each SEA school currently use non-proprietary MCU. VTEL has not released their proprietary MCU. The industry standard is only proprietary MCUs. 
VTEL now meets industry standard with its new Version 3.0 software. All of the SEA schools are using Version 2.0. To upgrade will cost from a few hundred dollars to several thousands, depending on the options that are needed. VTEL systems come with extended warranties. If the systems at the SEA schools are still under warranty, then the software upgrades will be done at not cost to the university. Each SEA university has committed to having Version 3.0 installed before the Fall ' 96 semester begins. This addition is expected to be implemented during Phase 2 of the distant learning course offering.

Overall, the course was a success (See Survey Form). A more accurate picture will emerge upon completion of the Course Survey Forms by the students. Also, with proper funding, students will be brought together in Phase 2 in a central location to administer the Final exam.

Relative to community involvement, using the EPA funded Environmental Justice Project (CEJAT) that are currently underway in the SEA region, cross training and regional interaction will be conducted using televideoconferencing (See Attached Press Release). This will enhance the effectiveness of the training, and provide the capability for the SEA to share critical environmental information across regional boundaries in a cost effective manner.

\section{April 4, 1997}

Current Status of Phase II: The course is currently underway for Spring '97. Prior to initiation of Phase II, Lawrence Livermore National Laboratory (LLNL) provided funds to the SEA Headquarters office for upgrading the video conferencing capability at each institution. Also, it was determined that the VTEL units at the SEA institutions were still under warranty. Therefore, the VTEL corporation upgraded the units from Version 2.0 to its Version 3.0 software at no cost to the institutions. At the start of the course, the SEA used the MCU bridging services of ACCESS International of Reston, Virginia, to handle the multi-point connections. Prairie View A\&M University (PVAMU) recently installed its own MCU bridge. Tests are underway to transfer all bridging responsibility for the course to PVAMU. Once PVAMU's MCU bridging capability is fully implemented, the Distant Learning Course will have demonstrated that a televideoconferencing linkage exist among the SEA member institutions. Having this capability will allow for a number of activities to be conducted among the institutions without the normal requirement of moving around large groups of people.

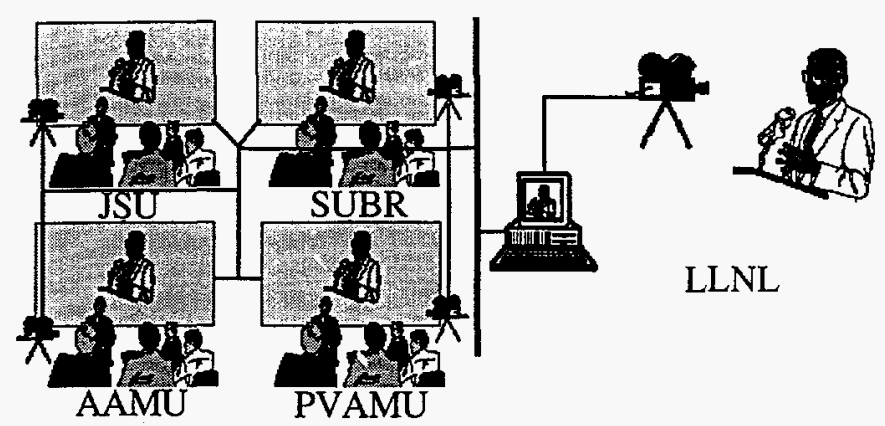

"Special Topics in Modern Molecular Biology" *BIO 380-01

(Spring 1996)

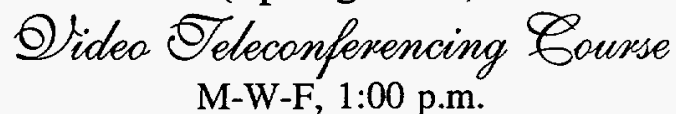

JAP 228 (Dean's Conference Room)

I. Introduction (Southem University at Baton Rouge [SUBR])

A. Molecular Genetics

B. DNA Technology

II. Applications

A. Biomedical Sciences

1. Chromosomes (Jackson State Univerity [JSU])

2. Forensic DNA Technology (Prairie View A\&M University [PVAMU])

3. Vaccines (SUBR)

4. Hemoglobin (JSU)

4. Hemoglobin (JSU)

B. Environmental Sciences (Alabama A\&M University [AAMU]/PVAMU)

1. Bioremediation

C. Agriculture Sciences (AAMU)

1. Genetic Engineering

a. Animals

*This course will substitute for Cell Biology (Bio 440).

Instructors: Dr. Mark Hardy, Dr. Balwant Sekhon, and Dr. Philip Jemilohun

Sponsored by The Science and Engineering Alliance (SEA) with support from the U.S. Department of Energy. 


\section{Collaborations Between SEA Faculty and Students and LLNL Technical Staff during Summer Program}

Faculty and Student Research Projects:

"Development of Optrode Fiber Optic Chemical Sensors for Weapons Monitoring and Exhaust Gas Sensing"

Kevin Langry, LLNL \& Rambabu Bobba, Southern University

"Sequencing the Sulfate Activation Iocus from Thiobacillus Ferrooxidans, a Bacterium which Plays an Important Role in Commercial Mining Operations of Copper, Uranium and Gold Ores"

Emilio Garcia, LLNL (Human Genome Center) \& Khairy Soliman, Alabama A\&M University \& student (Sophia Walker)

"Graphical User Interfaces (GUI's) and Implementation of a Neutral Particle Monte Carlo Code (MCNP) for Use on PC Platforms"

Tore Straume, LLNL \& Carl Drake, Jackson State University \& student (Ako Emanuel)

"Effects of Aerosol and Clouds Interactions on UV, PAR, and Crop Yields"

Allen Grossman, LLNL \& Guo \& Wang, Southern University

"In situ Bioremediation Techniques"

Mehdi Rashidi, LLNL \& Larry Cole, Prairie View A\&M University \& student (Andrew Karanja)

Student Research Projects (participation in summer program with LLNL mentor, but without SEA faculty member):

"Mapping of the LLNL Site Elevations to Produce A Drainage Plan Adequate to Handle Heavy Rainfall Years"

Vanessa Turner, Alabama A\&M University

"Validation of the Peregrine Code"

Paul Hillard, III, Southern University

"Bacteria Transport in Porous Media"

Adrienne Jordan, Prairie View A\&M University

"A Graphical Interactive Tool for the Investigation of Global Volcanic Aerosol Distribution Using the LLNL 2-D Chemical-Radiative-Transport Model" Jeremy Jackson, Southern University 


\section{SEA Scholarship/Incentive Awards Recipients}

Complete Listing of students that received SEA awards between 1991 and 1997. As shown, most of the Incentive Award recipients continued their education at an SEA institution. In 1996, awards were not given. Instead, SEA initiated a series of student roundtable sessions on the topic of the impact of change.

\begin{tabular}{|c|c|c|c|c|c|}
\hline NAME & $\begin{array}{l}\text { Year of } \\
\text { Award } \\
\end{array}$ & Major & Award Type & High School & $\begin{array}{l}\text { College/ } \\
\text { University }\end{array}$ \\
\hline Erika N. Brown & 1991 & Ph.D.MD & H.S. Incentive & Waller, TX & PVAMU \\
\hline Eva McSheila Owens & 1991 & BS/Comp. Science & H.S. Incentive & Yazoo City, MS & JSU \\
\hline Gloria Thomas & 1991 & Biomed. Engineering & H.S. Incentive & Scottlandville, LA & SUBR \\
\hline Jennifer L. Williams & 1991 & Food Scientist & H.S. Incentive & Hazelwood, AL & AAMU \\
\hline Ranti Bushura & 1991 & BS/Chem/Pharm.D & H.S. Incentive & Cardozo, D.C. & JSU \\
\hline Dorkina Myrick & 1991 & MD.Ph.D. in Patho. & Undergraduate & & PVAMU \\
\hline Pamela Dickerson & 1991 & Food Science & Undergraduate & & AAMU \\
\hline Patrice McDaniel & 1991 & Research Scientist & Undergraduate & & AAMU \\
\hline Thaddeus F. Harrison & 1991 & Comp. Modeling & Undergraduate & & JSU \\
\hline Yolanda Griffin & 1991 & Ph.D. Comp. Sci. & Undergraduate & & SUBR \\
\hline Aisha Swinton & 1992 & $N / A$ & H.S. Incentive & Callaway, MS & JSU \\
\hline Caliph Johnson, II & 1992 & N/A & H.S. Incentive & Booker T. Washington, TX & \\
\hline Craig Price & 1992 & MD. Mech. Eng. & H.S. Incentive & Booker T. Washington, TX & PVAMU \\
\hline Kenyatta I. Morrison & 1992 & Elect. Eng./Law Sch. & H.S. Incentive & Scottlandville, LA & SUBR \\
\hline Russell E. Caulfield & 1992 & Physics/ Math. & H.S. Incentive & Scottlandville, LA & SUBR \\
\hline Vanessa M. Turner & 1992 & Civil Engineering & H.S. Incentive & Dothan, AL & AAMU \\
\hline William Durr & 1992 & N/A & H.S. Incentive & Prentiss, MS & JSU \\
\hline Yakisha Nicole Forrester & 1992 & BS/Physics & H.S. Incentive & Butler, AL & AAMU \\
\hline Angelica Y. Dunlap & 1992 & MD./Ph.D./Sci. & Undergraduate & & PVAMU \\
\hline Ayesha X. Muhammad & 1992 & Genetics Research & Undergraduate & & AAMU \\
\hline Benny D. Cox II & 1992 & Ph.D./Physics & Undergraduate & & SUBR \\
\hline Bennyfer L. Bridgewater & 1992 & Ph.D./Engineering & Undergraduate & & SUBR \\
\hline Darlene Denise Davis & 1992 & Research Scientist & Undergraduate & & AAMU \\
\hline Koni Alaia Shaw & 1992 & Grad. School & Undergraduate & & AAMU \\
\hline LaJuan Jones & 1992 & Ph.D. & Undergraduate & & \\
\hline Latricia D. Edwards & 1992 & N/A & Undergraduate & & SUBR \\
\hline Niambi Sala White & 1992 & Biochemistry & Undergraduate & & JSU \\
\hline Nora Savage & 1992 & Masters/Civil Eng. & Undergraduate & & PVAMU \\
\hline Richard Crews & 1992 & Mechanical Engin. & Undergraduate & & PVAMU \\
\hline Tanya Monique Harris & 1992 & $N / A$ & Undergraduate & & JSU \\
\hline Theodore Lyons, II & 1992 & Ph.D./Sci. Res. & Undergraduate & & JSU \\
\hline Illane Torres & 1993 & Chemistry/Biology & H.S. Incentive & Cardozo, D.C. & $N / A$ \\
\hline Iris Camicia Baker & 1993 & Env. Scientist & H.S. Incentive & J. O. Johnson, AL & AAMU \\
\hline Keith I. Stokes & 1993 & Biology Pre. Med. & H.S. Incentive & Lanier, MS & JSU \\
\hline Lakeshia Israel & 1993 & Physical Sci./Eng. & H.S. Incentive & Booker T. Washington, TX & PVAMU \\
\hline Mamie E. Warren & 1993 & Mech. Engineering & H.S. Incentive & Booker T. Washington, TX & PVAMU \\
\hline Melvin D. Robinson & 1993 & Engineering & H.S. Incentive & Caldwell Parish, LA & SUBR \\
\hline Norman Atkins & 1993 & Biochemist & H.S. Incentive & Paramount, $\mathrm{AL}$ & AAMU \\
\hline Raymond McClean & 1993 & Medical Research & H.S. Incentive & Richard Montg., MD & Howard \\
\hline Riddell Flowers & 1993 & Chemist & H.S. Incentive & East Side, MS & JSU \\
\hline Rosemary Spraggins & 1993 & $N / A$ & H.S. Incentive & J. O. Johnson, AL & AAMU \\
\hline Tainisha Nicole Butler & 1993 & Civil Engineering & H.S. Incentive & Booker T. Washington, TX & PVAMU \\
\hline Tanitia Graham & 1993 & Biology/Medicine & H.S. Incentive & Murrah, MS & JSU \\
\hline
\end{tabular}




\begin{tabular}{|c|c|c|c|c|c|}
\hline NAME & $\begin{array}{l}\text { Year of } \\
\text { Award }\end{array}$ & Major & Award Type & High School & $\begin{array}{l}\text { Collegel } \\
\text { University }\end{array}$ \\
\hline Tracee W. Thomas & 1993 & Chem. Engineering & H.S. Incentive & Scottlandville H.S., LA & SUBR \\
\hline Althea G. Bluiett & 1993 & Ph.D. Research & Undergraduate & & PVAMU \\
\hline Angela M. Leslie & 1993 & Ph.D. & Undergraduate & & AAMU \\
\hline Ayanna Y. Swinton & 1993 & $N / A$ & Undergraduate & & JSU \\
\hline Bonique D. Pillot & 1993 & Ph.D./Physics & Undergraduate & & SUBR \\
\hline Caroline Cooper & 1993 & Research Career & Undergraduate & & AAMU \\
\hline Christina L Vaughn & 1993 & Veterinary Med. & Undergraduate & & AAMU \\
\hline Christopher Ford & 1993 & Plant Research & Undergraduate & & AAMU \\
\hline Danika Y. Moorer & 1993 & Ph.D. & Undergraduate & & JSU \\
\hline David Dubose & 1993 & Medicine & Undergraduate & & JSU \\
\hline Delicia E. Carey & 1993 & Ph.D. & Undergraduate & & AAMU \\
\hline Deshauda Tamita Graves & 1993 & Biology & Undergraduate & & PVAMU \\
\hline Donovan L. Hill & 1993 & Research Career & Undergraduate & & AAMU \\
\hline Ebonique C. Pillot & 1993 & Ph.D./Physics & Undergraduate & & SUBR \\
\hline Everett A. Larkin & 1993 & Ph.D./Engineering & Undergraduate & & PVAMU \\
\hline Jeffrey G. Scott & 1993 & $N / A$ & Undergraduate & & SUBR \\
\hline Jenatta Freeman & 1993 & $N / A$ & Undergraduate & & AAMU \\
\hline Juba Watss-Cain & 1993 & Ph.D./Physics & Undergraduate & & PVAMU \\
\hline Karl Duncan & 1993 & Ph.D./Teach @SUBR & Undergraduate & & SUBR \\
\hline Kasandra N. Guillory & 1993 & $N / A$ & Undergraduate & & SUBR \\
\hline Kristina N. Carey & 1993 & Ph.D./Research & Undergraduate & & SUBR \\
\hline Larry Jolivette & 1993 & Research Career & Undergraduate & & SUBR \\
\hline Melynda Price & 1993 & Ph.D. in Physics & Undergraduate & & PVAMU \\
\hline Michelle Marie Collins & 1993 & Medical Research & Undergraduate & & PVAMU \\
\hline Montee R. Withers & 1993 & Design Engineer & Undergraduate & & PVAMU \\
\hline Natasha Taylor & 1993 & MS in Mathematics & Undergraduate & & JSU \\
\hline Peneloppe Randall & 1993 & Ph.D./Research & Undergraduate & & SUBR \\
\hline Robert L. Moore & 1993 & Medical Research & Undergraduate & & JSU \\
\hline Robert R. Richardson & 1993 & Research & Undergraduate & & PVAMU \\
\hline Sharonda C. Ivy & 1993 & Electrical Eng. & Undergraduate & & JSU \\
\hline Sophia Yvonn Walker & 1993 & Medical Research & Undergraduate & & AAMU \\
\hline Steven R. Cunningham & 1993 & Orthopedic Surgeon & Undergraduate & & JSU \\
\hline Thelonius Dominic Chestan & 1993 & Ph.D. & Undergraduate & & AAMU \\
\hline Titania E. Dumas & 1993 & Grad. School & Undergraduate & & PVAMU \\
\hline Vennetta Y. Thomas & 1993 & $N / A$ & Undergraduate & & SLBR \\
\hline Victor T. Wyatt & 1993 & Biochemistry & Undergraduate & & JSU \\
\hline Yvette McGowan & 1993 & Computer Science & Undergraduate & & JSU \\
\hline Chantelle Lea McNeely & 1994 & Physics/Premed & H.S. Incentive & Glen Oaks, LA & SUBR \\
\hline ChaRandle Stanlett Jordan & 1994 & Ph.D. & H.S. Incentive & Meridian, MS & JSU \\
\hline Charles A. Gordon & 1994 & Biochemistry & H.S. Incentive & Woodrow Wilson, D.C. & Pittsburgh \\
\hline Chrishanda N. Moore & 1994 & Food Science & H.S. Incentive & Marengo High, AL & AAMU \\
\hline Christopher D. Harvey & 1994 & Medical Doctor & H.S. Incentive & Provine, AL & AAMU \\
\hline DeAndra Kimbrough & 1994 & Chemical Eng. & H.S. Incentive & Marengo, AL & AAMU \\
\hline Jason Myers & 1994 & $N / A$ & H.S. Incentive & Richard Montg., MD & $N / A$ \\
\hline Katrina L. Carter & 1994 & Physics/Chem./Math & H.S. Incentive & Baker, LA & SUBR \\
\hline Kenneth L. Johnson, Jr. & 1994 & Microbiology & H.S. Incentive & Oxon Hill, MD & Maryland \\
\hline Kevin D. Edwards & 1994 & Engineering & H.S. Incentive & Benjamin Bannekar, D.C. & Columbia \\
\hline Kinesha Latrece Harris & 1994 & Chemistry/Chem. Eng. & H.S. Incentive & Scottlandville, LA & SUBR \\
\hline Qantas Paul Judge & 1994 & Ph.D & H.S. Incentive & Scottlandville, LA & SUBR \\
\hline
\end{tabular}




\begin{tabular}{|c|c|c|c|c|c|}
\hline NAME & $\begin{array}{l}\text { Year of } \\
\text { Award }\end{array}$ & Major & Award Type & High School & $\begin{array}{l}\text { College/ } \\
\text { University }\end{array}$ \\
\hline Sharon DaNette Collins & 1994 & Physical Therapist & H.S. Incentive & Murrah, MS & JSU \\
\hline Tameka Glenez Hart & 1994 & $N / A$ & H.S. Incentive & Lanier, MS & JSU \\
\hline Tavares Thomas & 1994 & Chemical Eng. & H.S. Incentive & Marengo, AL & AAMU \\
\hline Thurmasia Omari Love & 1994 & MD. Civil Eng. & H.S. Incentive & Scottlandville, LA & SUBR \\
\hline Aaron Goode & 1994 & $N / A$ & Undergraduate & & AAMU \\
\hline Albert Dewayne Perry & 1994 & Mech. Eng. & Undergraduate & & PVAMU \\
\hline Alonia S. McCorvey & 1994 & Ph.D. & Undergraduate & & JSU \\
\hline Charles Edward West & 1994 & Mgmt. Info. Sys. & Undergraduate & & JSU \\
\hline Dena Devon Bilbrew & 1994 & Masters Degree & Undergraduate & & JSU \\
\hline Dwala N. Foster & 1994 & Ph.D. & Undergraduate & & SUBR \\
\hline Gary E. Crombie & 1994 & Electrical Eng. & Undergraduate & & PVAMU \\
\hline $\begin{array}{l}\text { Geralline G. Wilkerson } \\
\text { Halisa D. Parks (deceased) }\end{array}$ & $\begin{array}{l}1994 \\
1994\end{array}$ & $\begin{array}{l}\text { Masters Degree } \\
\text { Deceased }\end{array}$ & $\begin{array}{l}\text { Undergraduate } \\
\text { Undergraduate }\end{array}$ & & $\begin{array}{l}\text { JSU } \\
\text { PVAMU }\end{array}$ \\
\hline JoAnn Jackson & 1994 & Research Doctor & Undergraduate & & SUBR \\
\hline Johnny Boggs & 1994 & Environmental Bus. & Undergraduate & & AAMU \\
\hline Joy O'Nae Spurlock & 1994 & Ph.D. & Undergraduate & & SUBR \\
\hline Lauri Monica Nelson & 1994 & Ph.D./Organic Chem. & Undergraduate & & SUBR \\
\hline Rhonda Stout & 1994 & $N / A$ & Undergraduate & & AAMU \\
\hline Wichaune C. Porter & 1994 & N/A & Undergraduate & & AAMU \\
\hline Billy Williams & 1995 & $N / A$ & H.S. Incentive & Booker T. Washington, TX & \\
\hline Claude Curry & 1995 & N/A & H.S. Incentive & Piney Woods Ctry, MS & JSU \\
\hline Damiya Whitaker & 1995 & Medicine & H.S. Incentive & Cardozo, D.C. & Maryland \\
\hline Demeka Yvette Campbell & 1995 & Life Science & H.S. Incentive & Lee High School, AL & AAMU \\
\hline Elizabeth Codjoe & 1995 & Sports Medicine & H.S. Incentive & T.C. Williams, VA & $N / A$ \\
\hline Emily Anadu & 1995 & $N / A$ & H.S. Incentive & Booker T. Washington, TX & \\
\hline Jaimel D. Fowler & 1995 & Undecided & H.S. Incentive & Booker T. Washington, TX & \\
\hline Juba Jabulani Lomotey & 1995 & Physics & H.S. Incentive & Scottlandville, LA & SUBR \\
\hline Kimberly Nicole Johnson & 1995 & Pre Med/Biology & H.S. Incentive & Provine, MS & JSU \\
\hline LaKeisha Marie Bland & 1995 & Comp. Sci./Eng. & H.S. Incentive & Bailey Magnet, MS & JSU \\
\hline LaKeisha Renee Hill & 1995 & Env. Science & H.S. Incentive & Sumter County, AL & AAMU \\
\hline Marquis Deshun Rose & 1995 & Biology/Pre. Med. & H.S. Incentive & Provine High, MS & JSU \\
\hline Nakiya Whitaker & 1995 & Engineering & H.S. Incentive & Cardozo, D.C. & Maryland \\
\hline Oscar Julian Booker & 1995 & Pre. Med & H.S. Incentive & Carroll, LA & SUBR \\
\hline Ovid Timothy Hughes & 1995 & Chemical Eng. & H.S. Incentive & Scottlandville, LA & Moorehouse \\
\hline Rashaana Green & 1995 & $N / A$ & H.S. Incentive & Booker T. Washington, TX & \\
\hline Rashaune Denyse Payton & 1995 & Medicine & H.S. Incentive & Scottlandville, LA & SUBR \\
\hline Roberto Hinds & 1995 & Chem. Engineering & H.S. Incentive & Frederick Douglas, MD & N/A \\
\hline Roshonda Denise Lankford & 1995 & Biology & H.S. Incentive & Choetaw County, AL & AAMU \\
\hline Roy Garrick Sims & 1995 & Mech. Engineering & H.S. Incentive & Carroll, LA & SUBR \\
\hline Alton Marcello & 1995 & Chemistry & Undergraduate & & PVAMU \\
\hline Audra Robinson & 1995 & Ph.D. & Undergraduate & & JSU \\
\hline Carl R. Grant & 1995 & Physics/Comp. Sci. & Undergraduate & & SUBR \\
\hline Daniel E. Riley & 1995 & Mech. Engineering & Undergraduate & & PVAMU \\
\hline Darren Christopher Chung & 1995 & Biology & Undergraduate & & PVAMU \\
\hline George Richard White & 1995 & Masters Degree & Undergraduate & & JSU \\
\hline Jamila Rochelle Tillman & 1995 & Chemical Eng. & Undergraduate & & SUBR \\
\hline Kenya Denyse Curry & 1995 & BS/Ph.D. Physics & Undergraduate & & AAMU \\
\hline Kevin S. White & 1995 & Civil Engineering & Undergraduate & & PVAMU \\
\hline Lumumba Ato Barlow & 1995 & Mech. Engineering & Undergraduate & & SUBR \\
\hline
\end{tabular}




\begin{tabular}{|l|c|c|c|c|l|}
\hline NAME & $\begin{array}{c}\text { Year of } \\
\text { Award }\end{array}$ & Major & Award Type & High School & $\begin{array}{l}\text { Collegel } \\
\text { University }\end{array}$ \\
\hline Patrick Vaughan Grayson & 1995 & Physics/Electrical Eng. & Undergraduate & & \\
Rafael E. Luna & 1995 & Physics/Comp. Sci. & Undergraduate & & AAMU \\
Shonda Lanette Stewart & 1995 & Masters Degree & Undergraduate & & SUBR \\
Tiffany Vidette Norris & 1995 & Ph.D. & Undergraduate & & JSU \\
Vanessa A. Turner & 1995 & Civil Engineering & Undergraduate & & AAMU \\
Yashika Nichole Forrester & 1995 & BS in Physics & Undergraduate & & AAMU \\
Crystal Marshall & 1997 & Biotechnology & H.S. Incentive & T.C. Williams, VA & \\
Laelay Shimeles & 1997 & Electrical Eng. & H.S. Incentive & Cardozo, D.C. & \\
Shalanda Gerald & 1997 & Science & H.S. Incentive & Watkins Mill, MD & \\
\hline
\end{tabular}

\section{Legend:}

AAMU - Alabama A\&M University

JSU - Jackson State University

PVAMU - Prairie View A\&M University

SUBR - Southern University and A\&M College

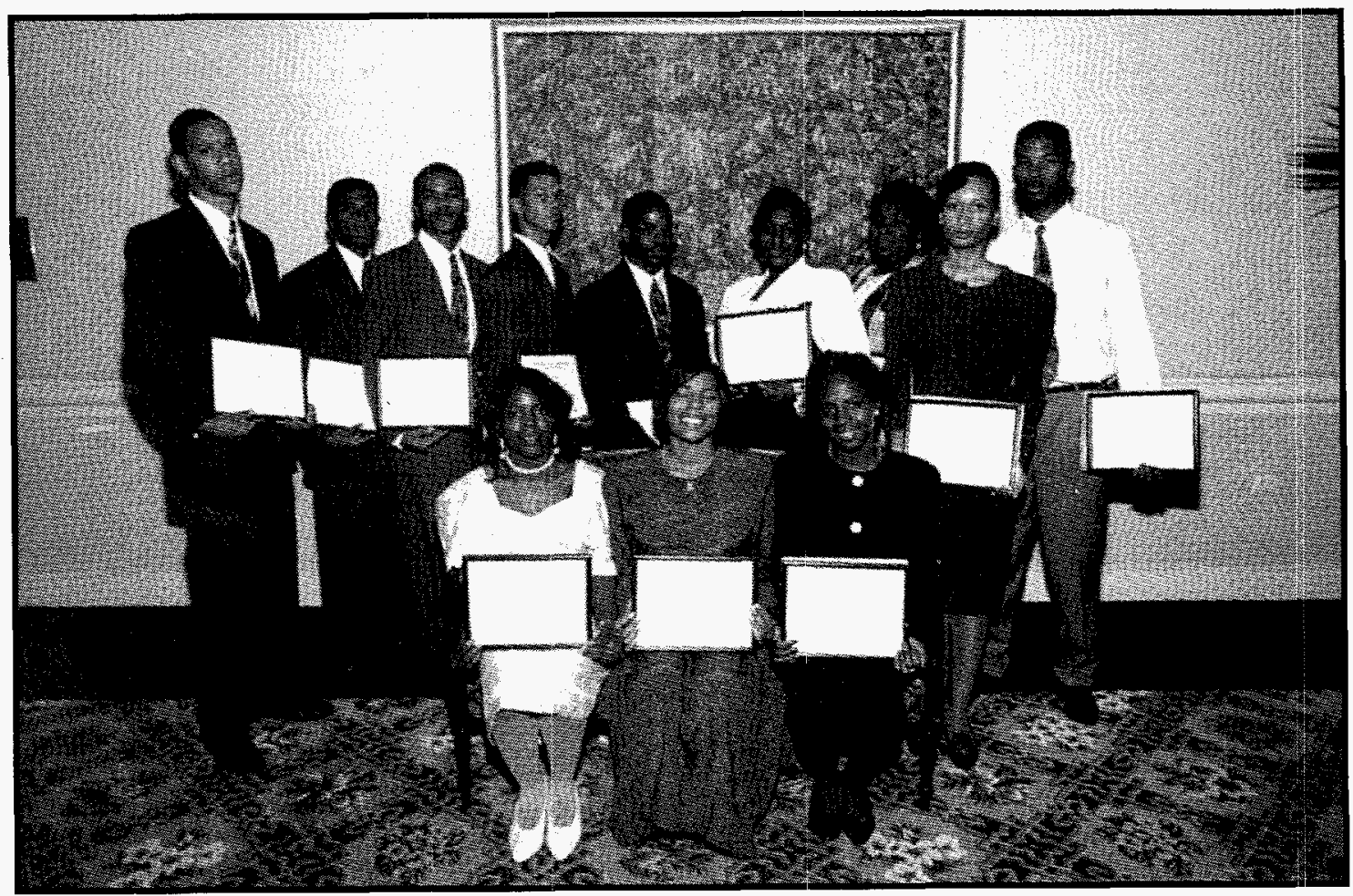

